\title{
Synthesis of Amino Indolizidines through the Chemoselective and Diastereoselective Catalytic Hydrogenation of Indolizines
}

María José Albaladejo, María José González-Soria and Francisco Alonso*

Instituto de Síntesis Orgánica (ISO) and Departamento de Química Orgánica, Facultad de Ciencias, Universidad de Alicante, Apdo. 99, 03080 Alicante (Spain)

E-mail: falonso@ua.es

\begin{abstract}
Indolizidines are great-potential bioactive heterocyclic compounds normally prepared following multi-step routes. However, to the best of our knowledge, the synthesis of 1-amino indolizidines has never been reported. Herein, 1-dialkylamino-3-substituted indolizidines have been straightforwardly synthesized using an atom-economy protocol which involves a copper-catalyzed three-component synthesis of indolizines followed by heterogeneous catalytic hydrogenation. The latter was found to be chemoselective using platinum(IV) oxide as the catalyst at $3.7 \mathrm{~atm}$, providing the amino indolizidines in modest-to-high yields (35-95\%) and high diastereoselectivity (92:8 to > 99:1). It has been experimentally demonstrated that the hydrogenation occurs through the intermediate 5,6,7,8-tetrahydroindolizine, which contains a pyrrole moiety. Moreover, the diastereomerically pure 1dibenzylamino-3-substituted indolizidines could be further transformed into the corresponding monobenzylated or fully debenzylated amino indolizidines by selective hydrogenolysis catalyzed by $\mathrm{Pt} / \mathrm{C}$ or $\mathrm{Pd} / \mathrm{C}$, respectively, under ambient conditions.
\end{abstract}




\section{INTRODUCTION}

There is a general upsurge of interest in developing new strategies to effectively obtain saturated Nheterocycles from readily accessible starting materials. This demand is supported by the potential development of new pharmaceuticals related to this type of heterocycles and their natural abundance. ${ }^{1}$ Among them, indolizidine alkaloids are widespread in nature and have attracted a great deal of attention because of their structural diversity and varied biological activity (Chart 1). ${ }^{2}$ For instance, indolizidine 167B was first found as a minor constituent in the skin secretions of a batrachian of the genus Dendrobates, ${ }^{3}$ whereas (+)-monomorine I was isolated from both Pharaoh’s ant Monomorium pharaonis and from bufonid toads of the Melanopbryniscus genus. ${ }^{4}(-)$-Tashiromine was first isolated from the stems of Maackia Tashiroi (Leguminosae), ${ }^{5 a}$ a bush from subtropical Asia, and later on from leaves and seeds of the Poecilanthe ${ }^{5 b}$ genus and from Ethiopian Crotalaria species. ${ }^{5 c}$ Swainsonine was first identified in the Australian legume Swainsona canescens ${ }^{6 a}$ and, subsequently, as the toxin in Astragalus and Oxytropis species that cause locoism in livestock. ${ }^{6 \mathrm{~b}}$ In contrast, the significance of swainsonine in the treatment of cancer and in immunology has been reported. ${ }^{6 \mathrm{c}}$ Indolizidines have also played an important role in the synthesis of other natural products. ${ }^{7}$

\section{Chart 1. Structure of some naturally occurring indolizidines.}
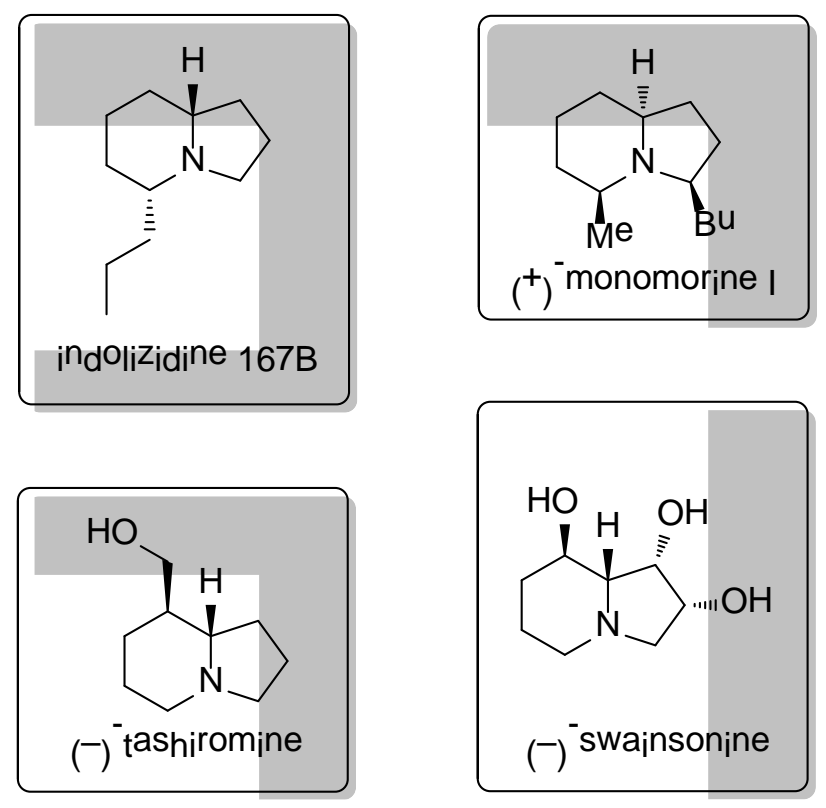
Different synthetic strategies have been developed to construct the indolizidine skeleton according to the substitution pattern pursued, ${ }^{8}$ including: (a) the use of pyrroles as building blocks, ${ }^{9}$ (b) from $\alpha$ aminoacids via stereocontrolled rhodium-catalyzed hydroformylation of $N$-allylpyrroles, ${ }^{10}$ (c) based on organosulfur and selenium chemistry (i.e., conjugate addition of nitrogen nucleophiles containing ester or chloroalkyl substituents to acetylenic sulfones, followed by base-mediated intramolecular alkylation or acylation), ${ }^{11}$ (d) by stereocontrolled cyclic nitrone cycloaddition, ${ }^{12}$ (e) by addition of allylsilanes to $N$-acyliminium ions, ${ }^{13}$ (f) by stereoselective conjugate addition reactions, ${ }^{14}$ (g) through radical azidation reactions, ${ }^{15}$ and (h) through chiral oxazolopiperidone lactams. ${ }^{16}$ However, despite the synthesis of indolizidines by the reduction of indolizines seems to be a direct approach, it has been barely documented and limited to some isolated examples. ${ }^{17}$ Other few reports describe the synthesis of indolizidines by heterogeneous catalytic hydrogenation of the pyrrole ring of 5,6,7,8tetrahydroindolizines. ${ }^{18}$ To the best of our knowledge, there is only one systematic study on the synthesis of indolizidines by full hydrogenation of indolizines, recently reported by Coelho et al. ${ }^{19}$ At any rate, partial reduction is a common problem encountered, which together with a desirable higher diastereoselectivity, ${ }^{20}$ make the selective hydrogenation of indolizines a challenging objective.

On the other hand, multicomponent heterocyclic synthesis is a effectual strategy to build diverse and complex structures in a sole operation and atom-economy fashion. ${ }^{21}$ Due to our interest and commitment to comprehend the reactivity of transition metal colloids, ${ }^{22}$ we presented a catalyst comprised of oxidized copper nanoparticles supported on activated carbon (CuNPs/C), which was easily obtained under soft conditions and highly versatile in the multicomponent click synthesis of 1,2,3-triazoles in water, using different azido precursors. ${ }^{23}$ More recently, the same catalyst was shown to be effective in the multicomponent synthesis of indolizines from pyridine-2-carbaldehyde derivatives, secondary amines and terminal alkynes. ${ }^{24}$ In this work we also introduce what is, to the best of our knowledge, the first example of a 1,3-disubstituted indolizidine bearing an amino group at the 1 position, obtained by catalytic hydrogenation of the corresponding indolizine. ${ }^{24 a}$ Herein, we wish 
to present a complete survey on our efforts to develop a straightforward synthesis of 1-amino-3substituted indolizidines based on the chemo- and diastereoselective catalytic hydrogenation of indolizines (Scheme 1).

\section{Scheme 1. Synthetic sequence toward 1-amino-3-substituted indolizidines.}

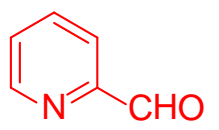

1
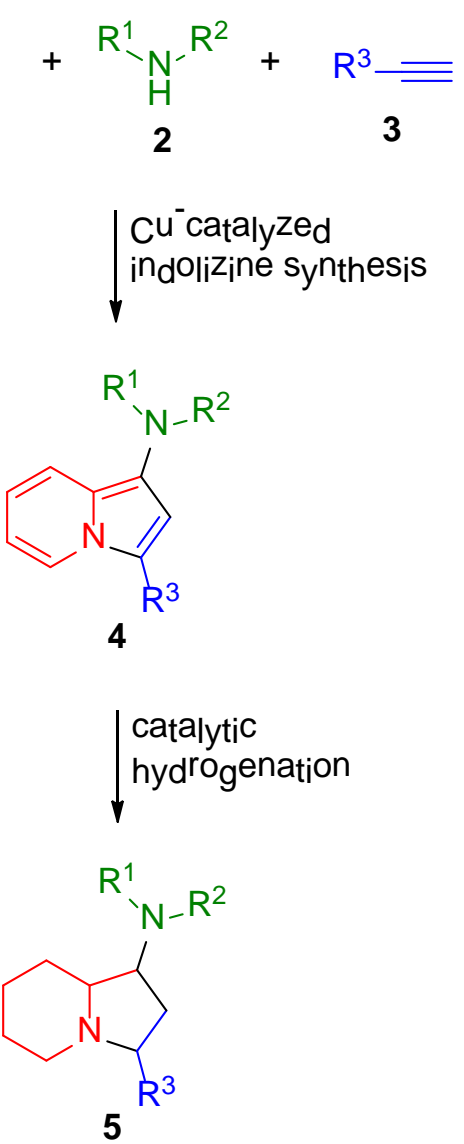

\section{RESULTS AND DISCUSSION}

First, we optimized the catalyst and reaction conditions for the catalytic hydrogenation of indolizines. $N, N$-Dibenzyl-3-phenylindolizin-1-amine (4h) was chosen as the model substrate because its hydrogenation was considered more challenging, due to the presence of three carbon-nitrogen bonds prone to undergo hydrogenolysis. In addition, the different hydrogenation degree for the five and sixmembered rings of the indolizine nucleus made the desired transformation more difficult to achieve. In 
Table 1. Hydrogenation of indolizine $4 \mathrm{~h}$ using platinum catalysts. ${ }^{a}$

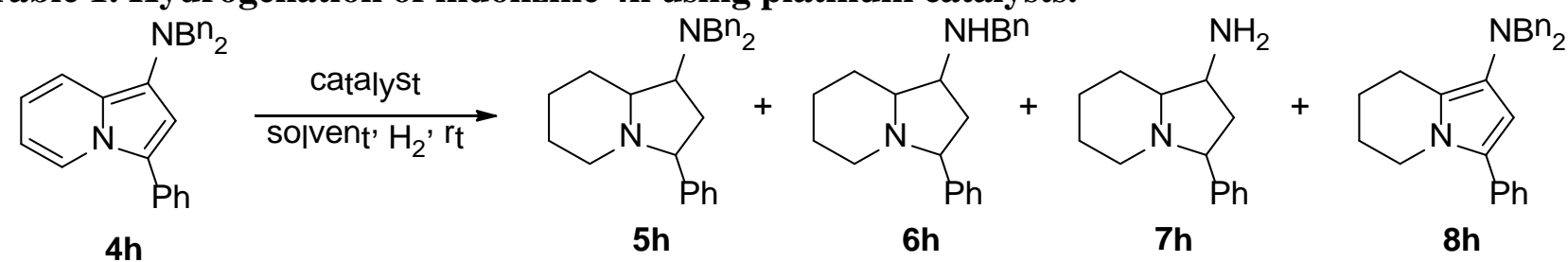

\begin{tabular}{|c|c|c|c|c|c|}
\hline Entry & Catalyst & Solvent & $P\left(\mathrm{H}_{2}, \mathrm{~atm}\right)$ & $t(\mathrm{~h})$ & $5 h / 6 h / 7 h / 8 h(\%)^{b}$ \\
\hline 1 & $\mathrm{PtO}_{2}$ & $\mathrm{MeOH}-\mathrm{CH}_{2} \mathrm{Cl}_{2}{ }^{c}$ & 1.0 & 72 & $47 /-/-/-$ \\
\hline 2 & $\mathrm{PtO}_{2}$ & $\mathrm{MeOH}-\mathrm{CH}_{2} \mathrm{Cl}_{2}{ }^{c}$ & 3.7 & 2 & $44 / 7 /-/ 6$ \\
\hline 3 & $\mathrm{PtO}_{2}$ & $\mathrm{EtOH}$ & 3.7 & 8 & 8/2/-/- \\
\hline 4 & $\mathrm{PtO}_{2}$ & $\mathrm{CH}_{2} \mathrm{Cl}_{2}$ & 3.7 & 2 & 8/-/-/- \\
\hline 5 & $\mathrm{PtO}_{2}$ & EtOAc & 3.7 & 2 & $23 /-/-/-$ \\
\hline 6 & $\mathrm{PtO}_{2}$ & EtOAc & 3.7 & 9 & 26/-/-/- \\
\hline 7 & $\mathrm{PtO}_{2}$ & HOAc & 1.0 & 24 & 39/-/-/- \\
\hline 8 & $\mathrm{PtO}_{2}$ & HOAC & 3.7 & 2 & $65 / 2 /-/ 21$ \\
\hline 9 & $\mathrm{PtO}_{2}$ & HOAC & 3.7 & 8 & $26 / 10 /-/ 5$ \\
\hline 10 & $\mathrm{PtO}_{2}$ & HOAc & 5.1 & 1 & $48 /-/-/-$ \\
\hline 11 & $\mathrm{PtO}_{2}{ }^{d}$ & HOAC & 3.7 & 2 & $40 /-/-/ 12$ \\
\hline 12 & $\mathrm{PtO}_{2}$ & HOAc & $1.0^{e}$ & 23 & $19 / 24 /-/ 25$ \\
\hline 13 & $\mathrm{PtO}_{2}$ & MeOH-HOAc ${ }^{f}$ & 3.7 & 2 & $53 /-/-/ 20$ \\
\hline 14 & $\mathrm{PtO}_{2}$ & $\mathrm{CH}_{2} \mathrm{Cl}_{2}-\mathrm{HOAC}^{f}$ & 3.7 & 2 & $65 / 13 /-/ 10$ \\
\hline 15 & $\mathrm{Pt}(1 \mathrm{wt} \%) / \mathrm{Al}_{2} \mathrm{O}_{3}$ & $\mathrm{MeOH}-\mathrm{CH}_{2} \mathrm{Cl}_{2}{ }^{c}$ & 3.7 & 2 & 31/-/-/- \\
\hline 16 & $\mathrm{Pt}(1 \mathrm{wt} \%) / \mathrm{Al}_{2} \mathrm{O}_{3}$ & HOAc & 3.7 & 2 & 55/-/-/- \\
\hline 17 & $\mathrm{Pt}(5 \mathrm{wt} \%) / \mathrm{Al}_{2} \mathrm{O}_{3}$ & HOAc & $1.0^{e}$ & 20 & $-/-/-/-$ \\
\hline 18 & $\operatorname{Pt}(5$ wt $\%) / \mathrm{CaCO}_{3}$ & HOAc & 3.7 & 3 & $62 / 14 /-/ 14$ \\
\hline 19 & $\operatorname{Pt}(5 \mathrm{wt} \%) / \mathrm{CaCO}_{3}{ }^{d}$ & HOAc & 3.7 & 3 & $57 / 7 /-/ 30$ \\
\hline 20 & $\mathrm{Pt}(5 \mathrm{wt} \%) / \mathrm{CaCO}_{3}$ & HOAC & $1.0^{e}$ & 20 & $10 / 23 /-/ 36$ \\
\hline 21 & $\mathrm{Pt}(5 \mathrm{wt} \%) / \mathrm{SiO}_{2}$ & HOAc & 3.7 & 3 & $-/-/-/-$ \\
\hline 22 & $\mathrm{Pt}(10$ wt\%)/C & $\mathrm{MeOH}-\mathrm{CH}_{2} \mathrm{Cl}_{2}{ }^{c}$ & 3.7 & 4 & $24 /-/-/-$ \\
\hline 23 & $\mathrm{Pt}(10 \mathrm{wt} \%) / \mathrm{C}$ & HOAc & 3.7 & 2 & $56 /-/-/-$ \\
\hline 24 & $\operatorname{Pt}(5$ wt\%)/C & HOAc & 3.7 & 3 & $68 / 6 /-/ 8$ \\
\hline 25 & $\operatorname{Pt}(5 \mathrm{wt} \%) / \mathrm{C}^{d}$ & HOAc & 3.7 & 3 & $52 / 7 /-/ 15$ \\
\hline 26 & $\mathrm{Pt}(5 \mathrm{wt} \%) / \mathrm{C}$ & HOAc & $1.0^{e}$ & 23 & 16/19/-/9 \\
\hline 27 & $\operatorname{Pt}(5$ wt\%)/C & HOAc & $1.0^{e}$ & $7^{g}$ & $30 / 14 /-/ 26$ \\
\hline 28 & $\operatorname{Pt}(5 \mathrm{wt} \%) / \mathrm{C}$ & HOAc & $1.0^{e}$ & $48^{g}$ & 22/46/-/- \\
\hline 29 & $\mathrm{Pt}(5 \mathrm{wt} \%) / \mathrm{C}$ & $\mathrm{MeOH}-\mathrm{HOAc} c^{c}$ & 3.7 & 3 & 9/5/-/- \\
\hline
\end{tabular}

${ }^{a}$ Reaction conditions: $\mathbf{4 h}(0.3 \mathrm{mmol})$, catalyst $(10 \mathrm{~mol} \%)$, solvent $(3.0 \mathrm{~mL})$ and $\mathrm{H}_{2}$ at rt. ${ }^{b}$ Conversion determined by GLC. ${ }^{c} 3: 1 \mathrm{v} / \mathrm{v} .{ }^{d} 5$ mol\%. ${ }^{e}$ In balloon. ${ }^{f} 1: 1 \mathrm{v} / \mathrm{v} .{ }^{g}$ Reaction at $50{ }^{\circ} \mathrm{C}$. 
principle, all reactions were carried out at room temperature with $10 \mathrm{~mol} \%$ of a platinum catalyst in different solvents or mixtures of solvents at various hydrogen pressures (Table 1); $\mathrm{MeOH}-\mathrm{CH}_{2} \mathrm{Cl}_{2}$ or $\mathrm{MeOH}-\mathrm{HOAc}$ mixtures favored solubilization of the starting indolizine with respect to the use of only MeOH. As regards the use of $\mathrm{PtO}_{2}$ as catalyst (Table 1, entries 1-14), higher pressure (3.7 atm) and shorter reaction time $(2 \mathrm{~h})$ increased the conversion into the desired indolizidine $\mathbf{5 h}$, particularly in the presence of HOAc as solvent (Table 1, entry 8); variable amounts of the mono-debenzylated indolizidine $\mathbf{6 h}$ and a semihydrogenation product (at this stage postulated to be $\mathbf{8 h}$ ) were also formed. Longer reaction time $(8 \mathrm{~h})$ at the same pressure had a detrimental effect on the conversion due to additional by-product formation (Table 1, compare entries 8 and 9). The combination of HOAc with either $\mathrm{MeOH}$ or $\mathrm{CH}_{2} \mathrm{Cl}_{2}$ gave quite good results but did not improve those reached with $\mathrm{PtO}_{2}$ (Table 1 , entries 13 and 14). Then, we explored the behavior of different platinum-based supported catalysts. The highest conversions were achieved with $\operatorname{Pt}(5 \mathrm{wt} \%) / \mathrm{CaCO}_{3}$ and $\operatorname{Pt}(5 \mathrm{wt} \%) / \mathrm{C}$ (Table 2, entries 18 and 24, respectively), likewise as above, when pressure (3.7 atm) and short reactions time ( $3 \mathrm{~h}$ ) were applied in $\mathrm{HOAc}$, with the concomitant formation of $\mathbf{6 h}$ and $\mathbf{8 h}$. As in the case of $\mathrm{PtO}_{2}$ (Table 1, entry 11), lower catalyst loading (5 mol\%) in the supported catalysts led to a decrease in the conversion though of a lower magnitude compared to the former (Table 1, entries 19 and 25).

Other metal catalysts were also tested with the aim to minimize by-product formation (Table 2). Pd(10 $\mathrm{wt} \%$ )/C provided a moderate conversion into $\mathbf{5} \mathbf{h}$ at ambient pressure and prolonged stirring in $\mathrm{MeOH}$, together with a substantial amount of mono-debenzylated $\mathbf{6 h}$ (Table 2, entry 1); higher hydrogen pressure shortened the reaction time but did not improve the conversion (Table 2, entry 2). An interesting effect of the pressure was noticed with $\mathrm{Pd}(20 \mathrm{wt} \%) / \mathrm{C}$ in HOAc, leading to $\mathbf{6 h}$ at 3.7 atm or 7h at ambient pressure with some selectivity (Table 2, entries 4 and 5). Unfortunately, any possibility for directly transforming the starting indolizine $4 \mathbf{h}$ into $\mathbf{6 h}$ or $\mathbf{7 h}$ by the choice of the pressure vanished because of the low diastereoselectivity attained in both cases (Table 2, footnotes $d$ and g). This lack of diastereoselectivity was also manifested with the deployment of $\mathrm{Pd}(5 \mathrm{wt} \%) / \mathrm{CaCO}_{3}$ which, conversely, 
was highly chemoselective towards the formation of $\mathbf{6 h}$ (Table 2, entry 7). Other catalysts, either heterogeneous $\left[\mathrm{Pd}(\mathrm{OH})_{2} / \mathrm{C}, \mathrm{Rh}(5 \mathrm{wt} \%) / \mathrm{C}\right.$ and $\left.\mathrm{Ru}(5 \mathrm{wt} \%) / \mathrm{C}\right]$ or homogeneous $\left\{[\mathrm{Rh}(\mathrm{COD}) \mathrm{Cl}]_{2}\right.$, $\left[\mathrm{RuCl}_{2}(p \text {-cymene })\right]_{2}$ and $\left.[\operatorname{Ir}(\mathrm{COD}) \mathrm{Cl}]_{2}\right\}$, and/or reaction conditions furnished complex reaction mixtures (Table 2, entries 6, 8, 9 and 11), no product (Table 2, entries 12-14) or a certain amount of $N$ benzylidene-3-phenylindolizin-1-amine, i.e. the imine of mono-debenzylated $\mathbf{6 h}$ (Table 2, entries 3, 16 and 17).

Table 2. Hydrogenation of indolizine $4 \mathrm{~h}$ using other metal catalysts. ${ }^{a}$

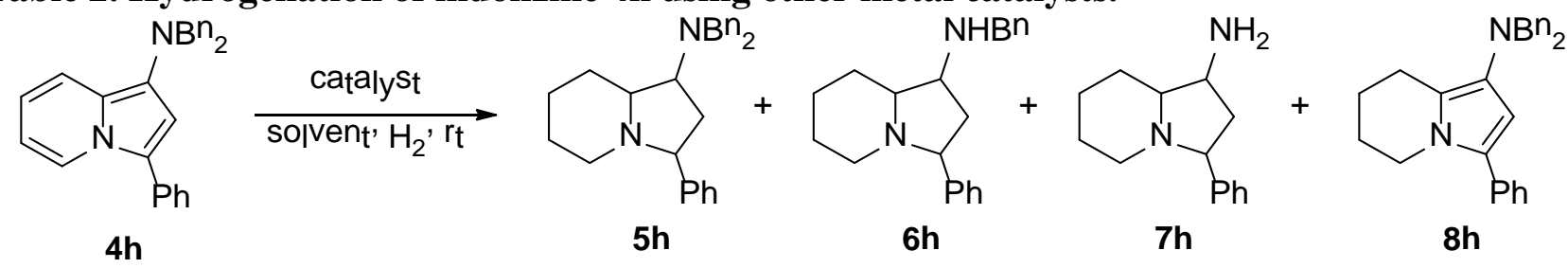

\begin{tabular}{|c|c|c|c|c|c|}
\hline Entry & Catalyst & Solvent & $P\left(\mathrm{H}_{2}\right.$, atm $)$ & $t(\mathrm{~h})$ & $5 \mathrm{~h} / 6 \mathrm{~h} / 7 \mathrm{~h} / 8 \mathrm{~h}(\%)^{b}$ \\
\hline 1 & $\operatorname{Pd}(10 \mathrm{wt} \%) / \mathrm{C}$ & $\mathrm{MeOH}$ & 1.0 & 48 & 64/19/-/- \\
\hline 2 & $\operatorname{Pd}(10 w t \%) / C$ & $\mathrm{MeOH}$ & 3.7 & 7 & $48 / 4 /-/-$ \\
\hline 3 & $\operatorname{Pd}(10 w t \%) / C$ & HOAc & 3.7 & 2 & $-{ }^{c}$ \\
\hline 4 & $\mathrm{Pd}(20 \mathrm{wt} \%) / \mathrm{C}$ & HOAc & 3.7 & 3 & $-/ 92^{d} / 8 /-$ \\
\hline 5 & $\operatorname{Pd}(20 w t \%) / C$ & HOAc & $1.0^{e}$ & 23 & $-/ 16^{f} / 64^{g} /-$ \\
\hline 6 & $\mathrm{Pd}(5 \mathrm{wt} \%) / \mathrm{CaCO}_{3}$ & HOAc & 3.7 & 3 & $-^{h}$ \\
\hline 7 & $\mathrm{Pd}(5 \mathrm{wt} \%) / \mathrm{CaCO}_{3}$ & HOAc & $1.0^{e}$ & 20 & $-/ 81^{i} /-/-$ \\
\hline 8 & $\mathrm{Pd}(\mathrm{OH})_{2} / \mathrm{C}$ & $\mathrm{MeOH}$ & 1.0 & 22 & $-h$ \\
\hline 9 & $\mathrm{Pd}(\mathrm{OH})_{2} / \mathrm{C}$ & $\mathrm{MeOH}-\mathrm{CH}_{2} \mathrm{Cl}_{2}^{j}$ & 1.0 & 13 & $-h$ \\
\hline 10 & $\mathrm{Pd}(\mathrm{OH})_{2} / \mathrm{C}$ & $\mathrm{MeOH}-\mathrm{CH}_{2} \mathrm{Cl}_{2}{ }^{j}$ & 3.7 & 6 & $-/ 27 /-/-$ \\
\hline 11 & $\mathrm{Pd}(\mathrm{OH})_{2} / \mathrm{C}$ & $\mathrm{MeOH}-\mathrm{CH}_{2} \mathrm{Cl}_{2}{ }^{k}$ & 1.0 & 15 & $-h$ \\
\hline 12 & $\mathrm{Rh}(5 \mathrm{wt} \%) / \mathrm{C}$ & HOAc & $1.0^{e}$ & 20 & - \\
\hline 13 & $\mathrm{Rh}(5 \mathrm{wt} \%) / \mathrm{C}$ & HOAc & 3.7 & 3.5 & - \\
\hline 14 & $\mathrm{Ru}(5 \mathrm{wt} \%) / \mathrm{C}$ & HOAc & 3.7 & 4 & - \\
\hline 15 & {$[\mathrm{Rh}(\mathrm{COD}) \mathrm{Cl}]_{2}$} & $\mathrm{MeOH}-\mathrm{CH}_{2} \mathrm{Cl}_{2}^{j}$ & 3.7 & 10 & $-l$ \\
\hline 16 & {$\left[\mathrm{RuCl}_{2}(p \text {-cymene })\right]_{2}$} & i-PrOH & 3.7 & 8 & $-{ }^{m}$ \\
\hline 17 & {$[\operatorname{Ir}(\mathrm{COD}) \mathrm{Cl}]_{2}$} & HOAc & 3.7 & 8 & $-n$ \\
\hline
\end{tabular}

${ }^{a}$ Reaction conditions: $4 \mathbf{h}(0.3 \mathrm{mmol})$, catalyst $(10 \mathrm{~mol} \%)$, solvent $(3.0 \mathrm{~mL})$ and $\mathrm{H}_{2}$ at $\mathrm{rt} .{ }^{b}$ Conversion determined by GLC. ${ }^{c}$ Monodebenzylated $\mathbf{4 h}$ (25\%) and its imine (35\%). ${ }^{d} 55: 45 d r$. ${ }^{e}$ In balloon.

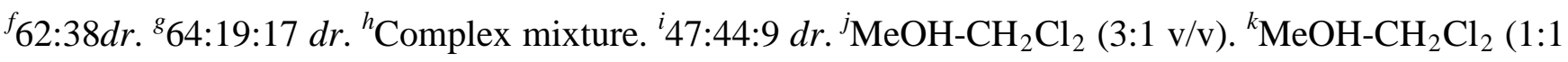


v/v). ${ }^{l}$ Unidentified product (29\%). ${ }^{m}$ Imine of monodebenzylated $\mathbf{4 h} \quad(12 \%) .{ }^{n}$ Imine of monodebenzylated $\mathbf{4 h}$ (4\%).

From this optimization study it can be concluded that $\mathrm{PtO}_{2}$ and $\mathrm{Pt}(5 \mathrm{wt} \%) / \mathrm{C}$ are the best catalysts in terms of conversion and selectivity (Table 1, entries 8 and 24, respectively). Given the heterogeneous nature of both catalysts, they are potentially recoverable and recyclable. ${ }^{25} \mathrm{PtO}_{2}$ could be easily reused by decantation, supernatant removal and catalyst washing in the same hydrogenation flask. In contrast, further manipulation and centrifugation were required for $\operatorname{Pt}(5 \mathrm{wt} \%) / \mathrm{C}$. For comparative purposes, all recycling experiments were conducted at 3.7 atm for $2 \mathrm{~h}$ (Figure 1). Catalyst reutilization was found to be more efficient with $\mathrm{PtO}_{2}$ than with $\mathrm{Pt}(5 \mathrm{wt} \%) / \mathrm{C}$ (60\% versus $36 \%$ in the second cycle). The catalytic activity of both catalysts decreased in subsequent cycles: 35 and $30 \%$ for $\mathrm{PtO}_{2}$ and $<10 \%$ for $\operatorname{Pt}(5 \mathrm{wt} \%) / C$, albeit better conversions would be expected for longer reaction times. In addition to this, we also observed that the catalytic performance of $\mathrm{Pt}(5 \mathrm{wt} \%) / \mathrm{C}$ with substrates other than $\mathbf{4 h}$ was lower than with $\mathrm{PtO}_{2}{ }^{26}$ In view of the aforementioned results, the catalytic system of choice was that composed of $\mathrm{PtO}_{2}$ (10 mol\%) in $\mathrm{HOAc}$ at 3.7 atm $\mathrm{H}_{2}$ (Table 1, entry 8).

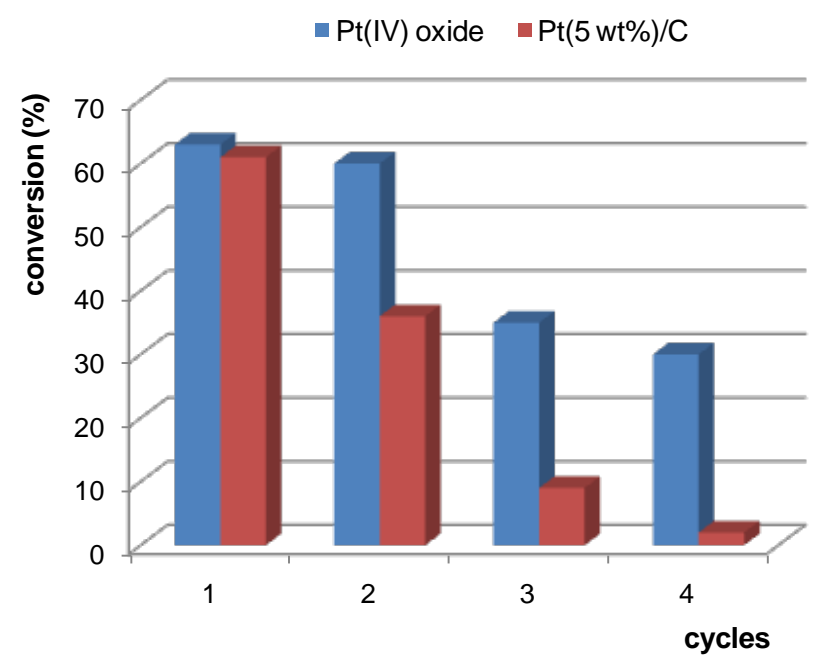

FIGURE 1. Catalyst recycling experiments in the hydrogenation of $4 \mathrm{~h}\left(3.7 \mathrm{~atm} \mathrm{H}_{2}, 2 \mathrm{~h}\right)$. 
In order to study the substrate scope, the optimized catalyst and reaction conditions were applied to a variety of indolizines 4, derived from pyridine-2-carbaldehyde (1a), secondary amines (2) and terminal alkynes (3), producing the expected indolizidines 5 in modest-to-high yields and with high-to-excellent diastereoselectivity (Table 3). The yield and diastereoselectivity were found to be dependent on the substituents at the 1 and 3 positions, with the amino group at the 1 position apparently exerting a stronger effect. For instance, the indolizines derived from piperidine and arylacetylenes were isolated in lower yields, with the lowest diastereoselectivity been recorded for the phenylacetylene derivative (5a). The diastereomeric ratio was improved when a para substituent was present in the arylacetylenederived moiety while at the same time maintaining the 1-piperidinyl group (Table 3, compare 5a with $\mathbf{5 b}$ and 5c). Fortunately, purification by column chromatography allowed the isolation of $\mathbf{5 a}$ and $\mathbf{5 b}$ as single diastereoisomers. Better yield and excellent diastereoselectivity were observed when changing the 1-piperidinyl into a 1-morpholino group (Table 3, compare 5a with 5d). In general, the results with acyclic amines were better than those with the cyclic counterparts concerning all, the yield, the diastereoselectivity and the reaction time. The diastereoselectivity increased when increasing the steric hindrance of the secondary amine (Table 3, compare 5e and $\mathbf{5 f}$ with $\mathbf{5 g}$ and $\mathbf{5 h}$ ). The indolizidines derived from dibenzylamine followed a similar trend to that of dibutylamine (5g), being generally obtained in relatively short hydrogenation reaction times and as single diastereoisomers (Table 3 , 5h$\mathbf{5 m}$ ). This remarkable behavior was displayed irrespective of the substituent at the 3 position of the indolizidine nucleus, including aryl substituents with electron-neutral (Table 3, 5h and 5i), -releasing (Table 3, 5j) and -withdrawing groups (Table 3, 5k and 5l), as well as aliphatic substituents (Table 3, $5 \mathrm{~m})$.

We endeavored to extend this method to more demanding indolizines in order to validate its applicability. Such is the case of $N, N$-dibutyl-1-phenylpyrrolo[1,2-a]quinolin-3-amine (4n), a benzofused indolizine coming from the coupling of quinoline-2-carbaldehyde (1b), dibutylamine (2e) and phenylacetylene (3a). It is worthy of note that its catalytic hydrogenation failed under the standard 
Table 3. Synthesis of the indolizidines $5 .^{a}$

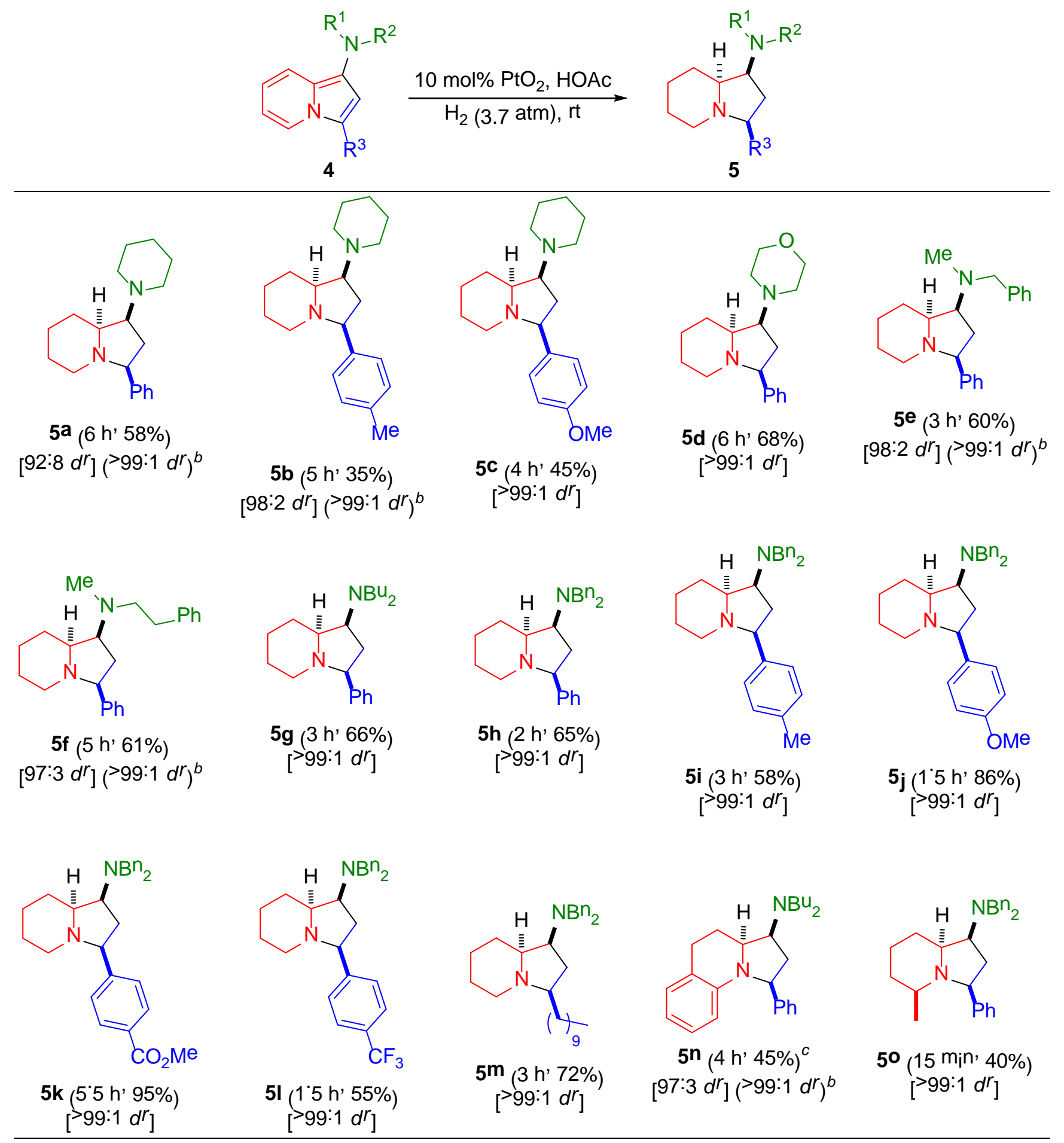

${ }^{a}$ Reaction conditions: 4 (0.5 mmol), $\mathrm{PtO}_{2}$ (10 mol\%), HOAc (3 mL), $\mathrm{H}_{2}$ (3.7 atm), rt; reaction time and isolated yield in parentheses; diastereomeric ratio in brackets determined by GC-MS from the reaction crude. ${ }^{b}$ Diastereomeric ratio after purification by column chromatography. ${ }^{c}$ Reaction at 4.1 atm. 
pressure and that a slightly higher pressure was necessary to initiate the reaction. Consequently, the latter was found to be more chemoselective at lower than at higher conversions, with an increase of byproduct formation in the second case. The scant yield of the expected hexahydropyrrolo[1,2-a]quinolin3-amine 5n was compensated for the high diastereomeric ratio reached; the presence of the fused benzene in the tricyclic indolizine core did not vary the stereochemical outcome with respect to the bicyclic counterparts. We went one step further by dealing with the hydrogenation of the trisubstituted indolizine 4o, the precursors of which were 6-methylpyridine-2-carbaldehyde (1c), dibenzylamine (2f) and phenylacetylene (3a). In this case, a short reaction time was more convenient to minimize byproduct formation. It was gratifying to know that, though in modest isolated yield, the four-stereocenter indolizidine 50 could be obtained with very high diastereoselectivity.

In some cases, by-products derived from the partial hydrogenation of the indolizine nucleus were detected in minor amounts. This fact, together with the relative high polarity of the indolizidines, made purification by column chromatography troublesome and accounted for some of the lower isolated yields recorded.

We were delighted to confirm that the indolizidine $5 \mathbf{h}$ could be obtained from pyridine-2carbaldehyde (1a), dibenzylamine (2f) and phenylacetylene (3a), without the need to isolate the intermediate indolizine (avoiding the corresponding work-up and purification) in a slightly higher yield than that obtained from the isolated indolizine (70 versus 65\%, Scheme 2). Therefore, this method represents a straightforward access into a new type of stereodefined indolizidines with three (or four) stereocenters. 


\section{Scheme 2. One-pot type synthesis of indolizidine $5 \mathrm{~h}$.}

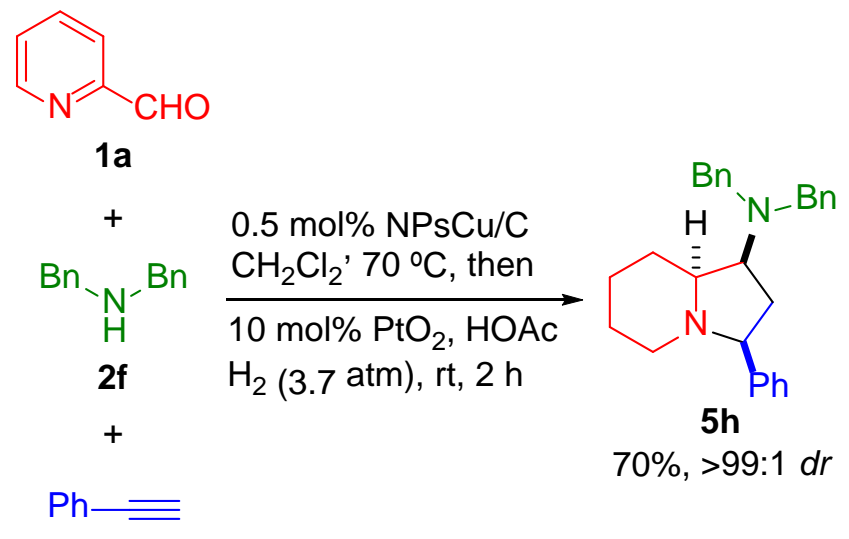

$3 a$

Secondary amines are versatile nitrogenated compounds with multiple applications in organic chemistry as, for example, as organocatalysts, ${ }^{27}$ as Lewis bases (e.g., for the activation of electrondeficient olefins ${ }^{28}$ or as building scaffolds for multicomponent reactions, ${ }^{29}$ among many others. On the other hand, in organic chemistry, it is desirable that the selective conversion of a single starting material into two or more different products can be accomplished by the selection of the catalyst. ${ }^{30}$ In this vein, attempts to directly transform indolizine $\mathbf{4 h}$ into the mono-benzylated secondary amine $\mathbf{6 h}$ were found to be successful in terms of conversion under palladium catalysis; regretfully, the diastereoselectivity of these reactions was too low (Table 2, entries 4 and 7, footnotes d and i). Then, we decided to take advantage of the presence of two benzyl groups in the indolizidines $\mathbf{5 h}-\mathbf{5 m}$ and $\mathbf{5 0}$ to investigate the possibilities of effecting selective hydrogenolyses, leading to secondary amines $\mathbf{6}$ or primary amines 7, through mono- and di-debenzylation processes, respectively.

Taking into account the information in tables 1 and 2, four catalysts were considered for this study, including platinum and palladium catalysts, using indolizidine $\mathbf{5 h}$ as the starting material (Table 4). As a general trend, platinum catalysts provided the mono-debenzylated product $\mathbf{6 h}$ whereas the palladium catalyst favoured the full debenzylated product $\mathbf{7 h}$. A significant effect of the hydrogen pressure was also discerned, with ambient pressure resulting in higher conversions and less formation of side 
products. Prolonged stirring was recommended in both cases because did not alter the high selectivity attained with the platinum catalysts $\left[\mathrm{Pt}(5 \mathrm{wt} \%) / \mathrm{C}\right.$ and $\left.\mathrm{PtO}_{2}\right]$ (Table 4, entries 3 and 4) and guaranteed the full hydrogenolysis with $\operatorname{Pd}(20 \mathrm{wt} \%) / \mathrm{C}$ (Table 4, compare entries 7 and 8).

Table 4. Optimization of the hydrogenolysis of $5 \mathrm{~h}$.

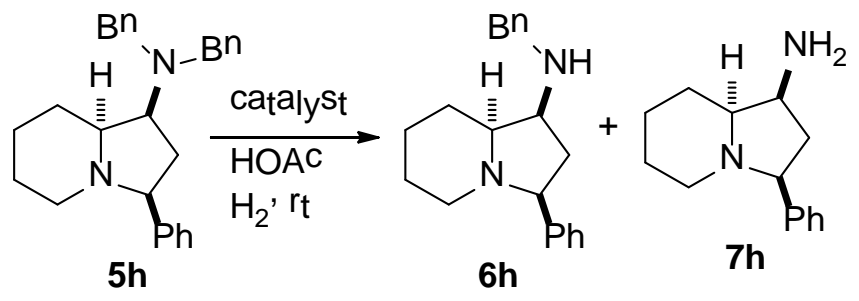

\begin{tabular}{ccccc}
\hline Entry & Catalyst & $P\left(\mathrm{H}_{2}\right.$, atm $)$ & $t(\mathrm{~h})$ & $\mathbf{6 h} / \mathbf{7 h}(\%)^{b}$ \\
\hline 1 & $\mathrm{Pt}(5 \mathrm{wt} \%) / \mathrm{C}$ & 3.7 & 2 & $15 /-$ \\
2 & $\mathrm{Pt}(5 \mathrm{wt} \%) / \mathrm{C}$ & 3.7 & 6 & $31 /-$ \\
$\mathbf{3}$ & $\mathbf{P t}(\mathbf{5} \mathbf{w t} \%) / \mathbf{C}$ & $\mathbf{1 . 0}^{c}$ & $\mathbf{2 2}$ & $\mathbf{6 1 / -}$ \\
$\mathbf{4}$ & $\mathbf{P t O}$ & $\mathbf{1 . 0}{ }^{c}$ & $\mathbf{1 7}$ & $\mathbf{8 3 / -}$ \\
5 & $\mathrm{Pt}(5 \mathrm{wt} \%) / \mathrm{CaCO}_{3}$ & $1.0^{c}$ & 16 & $59 /-$ \\
6 & $\mathrm{Pd}(20 \mathrm{wt} \%) / \mathrm{C}$ & 3.7 & 2 & $31 /-$ \\
7 & $\mathrm{Pd}(20 \mathrm{wt} \%) / \mathrm{C}$ & $1.0^{c}$ & 7 & $6 / 77$ \\
$\mathbf{8}$ & $\mathbf{P d}(\mathbf{2 0} \mathbf{w t} \%) / \mathbf{C}$ & $\mathbf{1 . 0}^{c}$ & $\mathbf{2 3}$ & $\mathbf{- / 8 2}$ \\
\hline
\end{tabular}

${ }^{a}$ Reaction conditions: $5 \mathbf{h}(0.3 \mathrm{mmol})$, catalyst $(10 \mathrm{~mol} \%), \mathrm{HOAc}(3.0 \mathrm{~mL})$ and $\mathrm{H}_{2}$ at rt. ${ }^{b}$ Conversion determined by GLC. ${ }^{c}$ In balloon.

The optimized conditions were first applied to the selective mono-debenzylation of some of the indolizidines $\mathbf{5 h}-\mathbf{5 m}$. As representative examples, indolizidines derived from aromatic alkynes of diverse electronic nature (neutral, rich and deficient ones), as well as from aliphatic alkynes, were converted into the monobenzylated counterparts 6 in moderate-to-high yields (Table 5). Although both catalysts, $\mathrm{PtO}_{2}$ and $\mathrm{Pt}(5 \mathrm{wt} \%) / \mathrm{C}$ selectively catalyzed the mono-debenzylation reaction at ambient hydrogen pressure and temperature, the yields were slightly higher when the former was utilized for $\mathbf{5 h}$ and $\mathbf{5 j}$, and the latter for $\mathbf{5} \mathbf{l}$ and $\mathbf{5 m}$. 
Table 5. Mono-debenzylation of indolizidines $5 .^{a}$

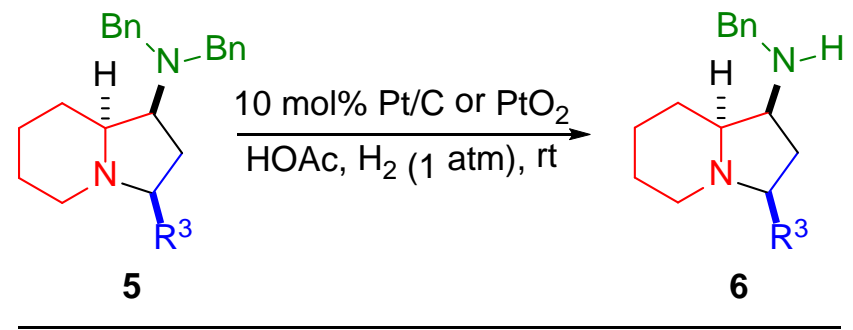

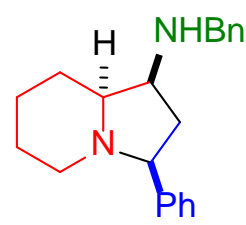

$6 \mathrm{~h}$

$17 \mathrm{~h}, 68 \%^{b}$

$>99: 1 d r$

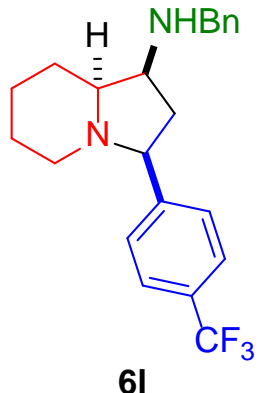

$19 \mathrm{~h}, 65 \%^{\mathrm{c}}$ $>99: 1 d r$

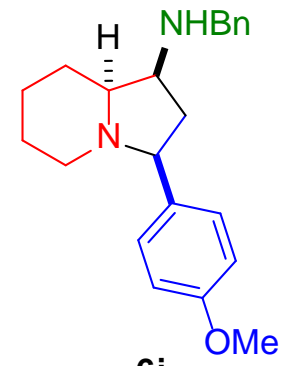

6j

$24 \mathrm{~h}, 72 \%{ }^{b}$

$>99: 1 d r$

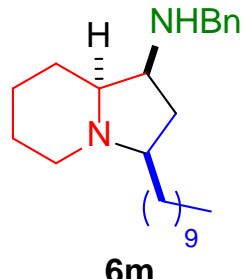

$23 \mathrm{~h}, 81 \%^{\mathrm{c}}$

$>99: 1 d r$

${ }^{a}$ Reaction conditions: 5 (0.3 mmol), catalyst (10 mol\%), HOAc (3.0 mL) and $\mathrm{H}_{2}(1 \mathrm{~atm})$ at rt; isolated yield after purification by preparative TLC (hexane/EtOAc 6:4); conversions into 6 were in the range 82->99\%); diastereomeric ratio determined by GC-MS from the reaction crude. ${ }^{b}$ Reaction catalyzed by $\mathrm{PtO}_{2} \cdot{ }^{c}$ Reaction catalyzed by $\mathrm{Pt}(5 \mathrm{wt} \%) / \mathrm{C}$.

When the same substrates, as above, were submitted to hydrogenolysis catalyzed by $\mathrm{Pd}(20 \mathrm{wt} \%) / \mathrm{C}$ at ambient hydrogen pressure and temperature, the corresponding free amino indolizidines 7 were produced in high yields as a result of a di-debenzylation process (Table 6). It is noteworthy that the original stereochemical integrity of the indolizidines was unaffected during the hydrogenolyses leading to the desired products as single diastereomers. 
Table 6. Di-debenzylation of indolizidines $5 .^{a}$
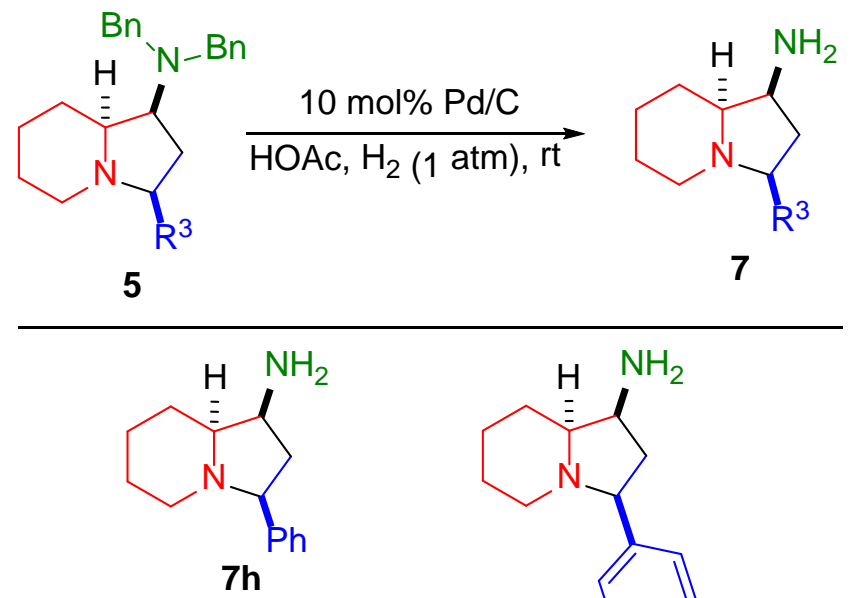

23 h, $85 \%$ $>99: 1 d r$

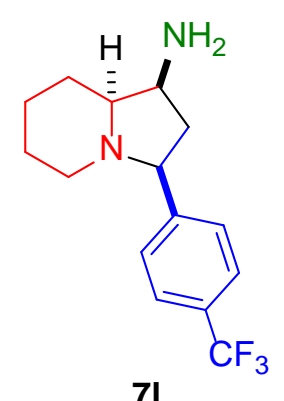

71

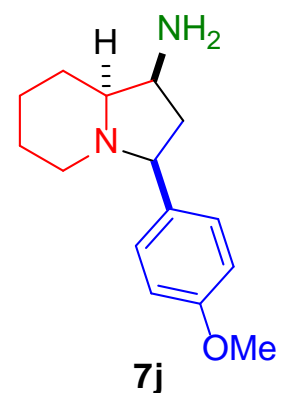

22 h, $77 \%$

16 h, $74 \%$

$>99: 1 d r$

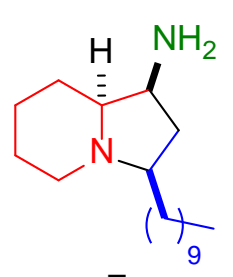

$7 \mathrm{~m}$ $>99: 1 d r$

${ }^{a}$ Reaction conditions: 5 (0.3 mmol), Pd(20 wt\%)/C (10 mol\%), HOAc (3.0 mL) and $\mathrm{H}_{2}(1 \mathrm{~atm})$ at rt; conversions into 7 were in the range $73->99 \%$. Compounds $\mathbf{7 h}$ and $\mathbf{7 l}$ were purified by preparative TLC (EtOAc). Compounds $\mathbf{7 j}$ and $\mathbf{7 m}$ did not require any further purification. Diastereomeric ratio determined by GC-MS from the reaction crude.

The stereochemistry of the indolizidines 5 was originally proposed on the basis of 2D-NMR experiments conducted for $\mathbf{5 d}$, $\mathbf{5 h}, \mathbf{5 n}$ and $\mathbf{5 o}$ (Figure 2) and, later on, unequivocally established by Xray crystallographic analysis of compound 5 a (Figure 3). ${ }^{31}$ In view of these data, the major diastereoisomer obtained in the catalytic hydrogenation of the indolizines is that resulting from the addition of hydrogen to the same face of the indolizine nucleus. 

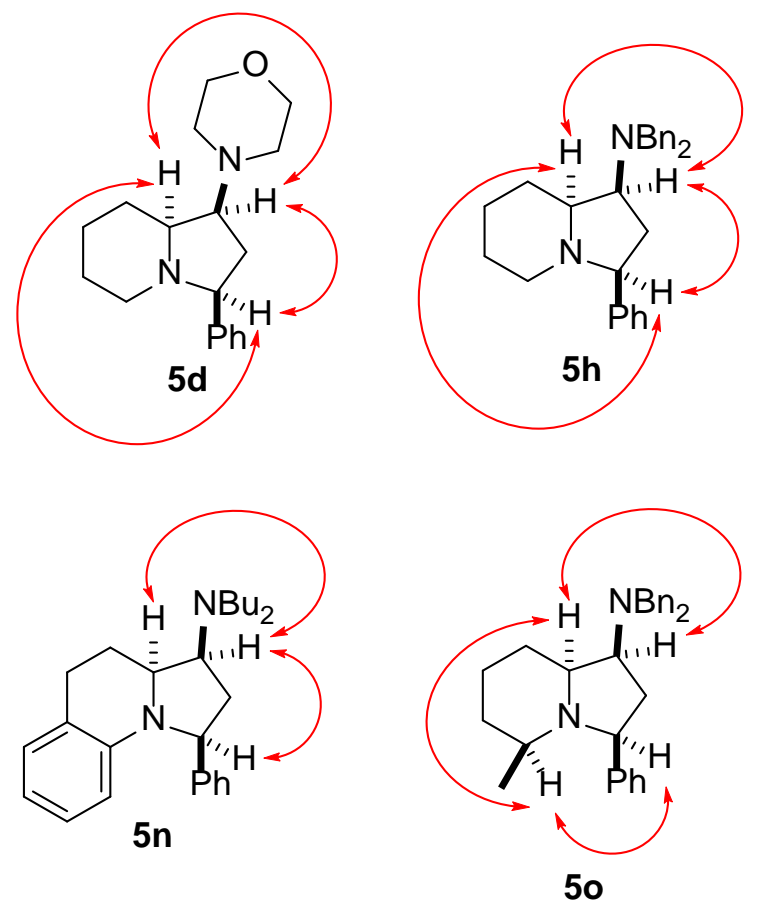

FIGURE 2. Selected ${ }^{1} \mathrm{H}-{ }^{1} \mathrm{H}$ correlations from NOESY experiments.

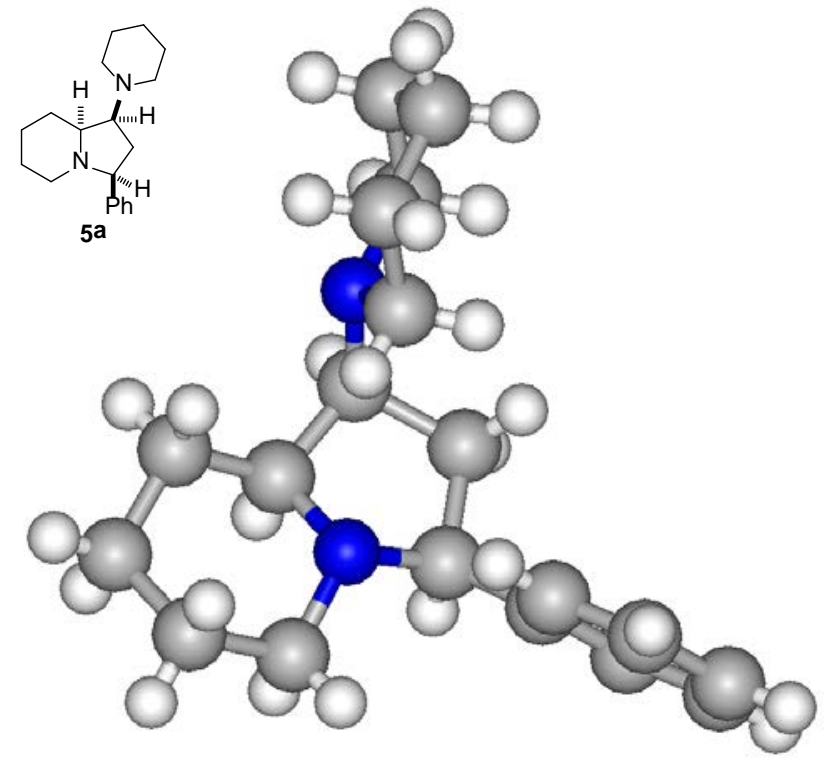

FIGURE 3. X-ray structure of compound 5 a. 
Finally, we were intrigued to know about the hydrogenation pathway and the structure of any possible semihydrogenated intermediate. With this purpose in mind, indolizine 4a was hydrogenated under the standard conditions but for a shorter reaction time. These intermediates were found to be rather elusive because of their minor formation and high tendency to over-hydrogenation. Notwithstanding these added difficulties, we managed to isolate a certain amount of the 5,6,7,8-tetrahydroindolizine 8a, which confirmed the preferential hydrogenation of the six-membered ring of the indolizine nucleus. Further hydrogenation of $\mathbf{8 a}$ gave rise to the fully reduced indolizidine 5a with the same stereoselectivity as above. These results lend weight to the argument that the stereochemistry of the indolizidines is fixed in a second stage, where all hydrogen atoms are delivered from the catalyst to the same face of the pyrrole ring in 8a (Scheme 3).

Scheme 3. Sequential hydrogenation of the indolizine 4a and hydrogenation model of 8 a.
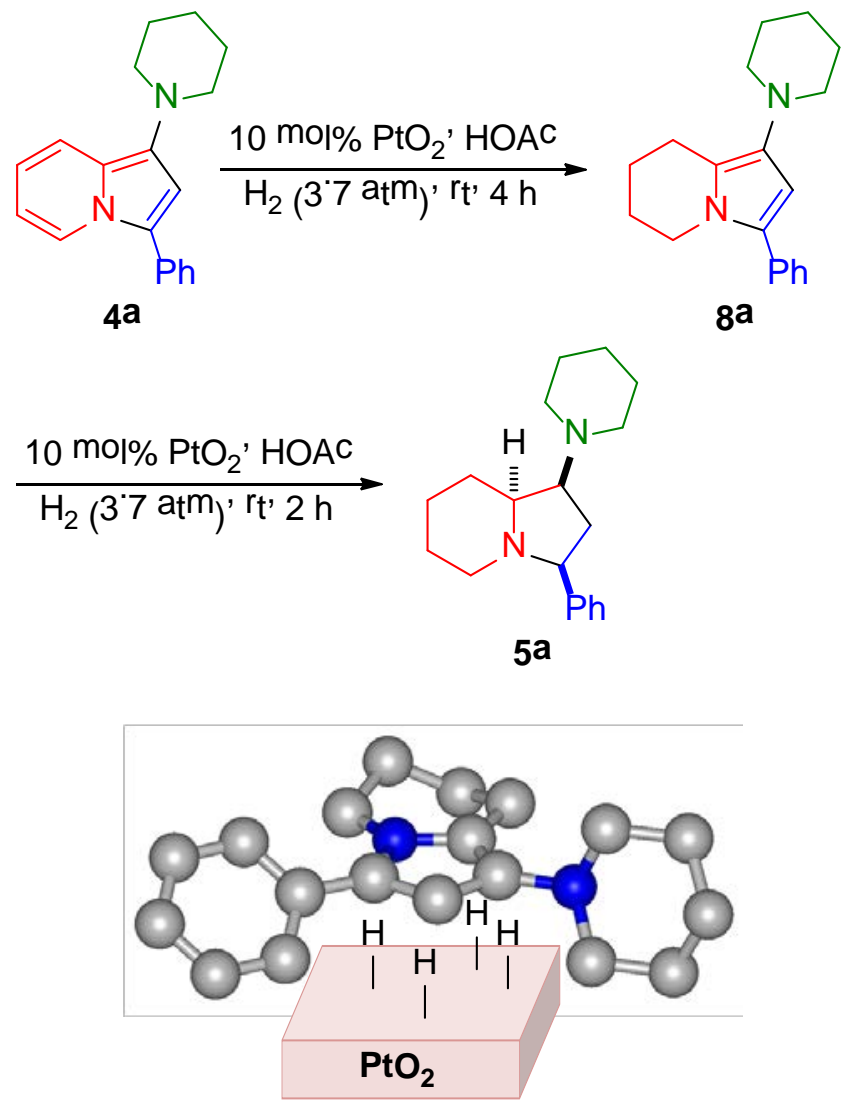


\section{CONCLUSION}

A series of 1-amino substituted indolizidines have been synthesized from readily available indolizines by heterogeneous catalytic hydrogenation. By the choice of the catalyst $\left(\mathrm{PtO}_{2}, \mathrm{Pt} / \mathrm{C}\right.$ or $\left.\mathrm{Pd} / \mathrm{C}\right)$, tertiary, secondary or primary amino-substituted indolizidines are selectively produced in modest-to-excellent yields (35-95\%), mostly, as single diastereomers (with three or four stereocenters). Experimental evidence supports the indolizine hydrogenation occurring through the pyrrolic intermediate 5,6,7,8tetrahydroindolizine. Furthermore, the indolizidine synthesis can be sequentially and successfully implemented by the copper-catalyzed multicomponent synthesis of the indolizine nucleus followed by the platinum-catalyzed heterogeneous hydrogenation, without the need to isolate the intermediate indolizine. This approach represents a direct pathway to a new type of indolizidines.

\section{EXPERIMENTAL SECTION}

General: Platinum(IV) oxide (Acros), Pt(5 wt\%)/C (Evonik) and $\operatorname{Pd}(20$ wt\%)/C (Evonik) were commercially available. Catalytic hydrogenation was carried out in a Parr hydrogenation apparatus using a $500 \mathrm{~mL}$ flask. Melting points are uncorrected. Infrared analysis was performed with a FT-IR spectrophotometer equipped with an ATR component; wavenumbers are given in $\mathrm{cm}^{-1}$. NMR spectra were recorded at 300 or $400 \mathrm{MHz}$ for ${ }^{1} \mathrm{H}$ NMR and 75 and $101 \mathrm{MHz}$ for ${ }^{13} \mathrm{C} \mathrm{NMR}$; chemical shifts are given in $(\delta)$ parts per million and coupling constants $(J)$ in Hertz. Mass spectra (EI) were obtained at 70 eV with a GC-MS apparatus; fragment ions in $\mathrm{m} / \mathrm{z}$ with relative intensities (\%) in parentheses. HRMS analyses were carried out in the electron impact mode (EI) at $70 \mathrm{eV}$ using a quadrupole analyzer or with a LC-ESI-TOF system. Elemental analysis was performed on a CHNS microanalyzer. X-ray data collection was based on three $\omega$-scan runs (starting $\omega=-34^{\circ}$ ) at the values of $\phi=0^{\circ}, 120^{\circ}, 240^{\circ}$ with the detector at $2 \theta=-32^{\circ}$. An additional run at $\phi=0^{\circ}$ of 100 frames was collected to improve redundancy. The diffraction frames were integrated using the SAINT program and the integrated 
intensities were corrected for Lorentz-polarization effects with SADABS. ${ }^{32}$ The purity of volatile compounds and the chromatographic analyses (GLC) were determined with a gas chromatograph equipped with a flame ionization detector and a $30 \mathrm{~m}$ capillary column $(0.32 \mathrm{~mm}$ diameter, $0.25 \mu \mathrm{m}$ film thickness), using nitrogen $(2 \mathrm{~mL} / \mathrm{min})$ as carrier gas, $T_{\text {injector }}=270{ }^{\circ} \mathrm{C}, T_{\text {column }}=60{ }^{\circ} \mathrm{C}(3 \mathrm{~min})$ and $60-270{ }^{\circ} \mathrm{C}\left(15^{\circ} \mathrm{C} / \mathrm{min}\right)$; retention times $\left(t_{\mathrm{R}}\right)$ are given in min. Thin-layer chromatography was carried out on TLC aluminum sheets covered with silica gel. Column chromatography was performed using silica gel of 40-60 microns (hexane/EtOAc as eluent). Preparative thin-layer chromatography was carried on laboratory-made TLC glass plates with silica gel $60 \mathrm{PF}_{254}$ (hexane/EtOAc or EtOAc).

General procedure for the synthesis of the indolizines 4: The indolizines 4 were prepared from pyridine-2-carbaldehyde derivatives, secondary amines and terminal alkynes according to our previously published procedure. ${ }^{24}$ The aldehyde (1, $\left.0.5 \mathrm{mmol}\right)$, amine (2, $\left.0.5 \mathrm{mmol}\right)$ and alkyne (3, 0.5 mmol) were added to a reactor tube containing CuNPs/C (20 mg, ca. $0.5 \mathrm{~mol} \%$ ) and dichloromethane $(1.0 \mathrm{~mL})$. The reaction mixture was warmed to $70{ }^{\circ} \mathrm{C}$ without the exclusion of air and monitored by TLC and/or GLC until total or steady conversion of the starting materials. The solvent was removed in vacuo; EtOAc $(2 \mathrm{~mL})$ was added to the resulting mixture followed by filtration through Celite and washing with additional EtOAc $(4 \mathrm{~mL})$. The reaction crude obtained after evaporation of the solvent was purified by column chromatography (silica gel, hexane/EtOAc) to give the corresponding indolizine 4. The physical and spectroscopic data of the new indolizine 40 follow:

$N, N$-Dibenzyl-5-methyl-3-phenylindolizin-1-amine (4o): yellow oil (247 mg, 61\%); $t_{\mathrm{R}} 29.11 ; R_{f} 0.73$ (hexane/EtOAc, 8:2); IR (neat) v 3079, 3066, 3027, 2925, 2827, 1599, 1492, 1472, 1451, 1292, 1070, 748, 696; ${ }^{1} \mathrm{H}$ NMR (300 MHz, $\mathrm{CDCl}_{3}$ ) $\delta$ 2.01(s, 3H), 4.17 (s, 4H), 6.13 (d, $\left.J=6.5 \mathrm{~Hz}, 1 \mathrm{H}\right), 6.48$ (dd, $J$ = 8.8, 6.5 Hz, 1H), 6.55 (s, 1H), 7.14-7.29 (m, 11H), 7.37 (d, J = 7.0 Hz, 1H), 7.49 (d, J= 8.9 Hz, 1H);

${ }^{13} \mathrm{C}$ NMR $\left(75 \mathrm{MHz}, \mathrm{CDCl}_{3}\right) \delta 23.0,59.4,111.4,111.9,114.7,115.6,126.7,126.8,127.0,128.0,128.6$, 
130.9, 123.5, 127.2, 134.0, 136.0, 139.6; MS (EI) m/z 402 (M+, 0.3), 311 (23), 310 (99), 309 (39), 295

(10), 281 (18), 221 (10), 209 (13), 208 (24), 207 (100), 191 (17), 91 (26); HRMS (ESI) m/z: [M] Calcd for $\mathrm{C}_{29} \mathrm{H}_{26} \mathrm{~N}_{2}$ 402.2096; Found 402.2093.

General procedure for the optimization of the catalytic hydrogenation: A suspension of the indolizine $4 \mathbf{h}(0.3 \mathrm{mmol})$ and catalyst $(0.03 \mathrm{mmol})$ in glacial HOAc $(3 \mathrm{~mL})$ was hydrogenated at different pressures and reaction times, at room temperature, as indicated in Tables 1 and 2. The catalyst was removed by filtration and the resulting mixture was diluted with EtOAc and analyzed by GLC, TLC and GC-MS.

General procedure for the hydrogenation of indolizines 4 catalyzed by $\mathbf{P t O}_{2}$ : The indolizine 4 (0.5 mmol) was poured into the hydrogenation flask, followed by the addition of $\mathrm{PtO}_{2}(11.4 \mathrm{mg}, 10 \mathrm{~mol} \%)$ and glacial HOAc (3 mL), with this mixture being subjected to hydrogenation at 3.74 atm (55 psi) and ambient temperature. The reaction was monitored by TLC and/or GLC until total or steady conversion of the starting material (see Table 2). The catalyst was separated by filtration and the solvent was removed under vacuum. Purification of the reaction crude by column chromatography (silica gel, hexane/EtOAc) afforded the pure indolizidines $\mathbf{5}$ as single diastereoisomers.

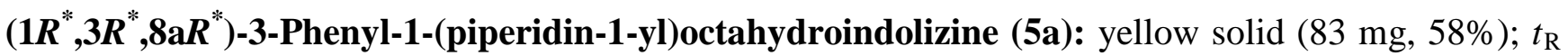
12.62; $R_{f} 0.40$ (hexane/EtOAc, 4:6); mp 68.9-70.9 ${ }^{\circ} \mathrm{C}(\mathrm{EtOH}) ; \mathrm{IR}$ (neat) $v$ 3084, 3050, 3030, 2929, 2851, 2789, 2789, 1601, 1439, 1364, 1260, 1142, 1126, 1105, 863, 755, 698; ${ }^{1} \mathrm{H}$ NMR (400 MHz, $\left.\mathrm{CDCl}_{3}\right) \delta 1.13-1.26,1.34-1.66,1.71-1.85,1.98-2.11,2.29-2.40,2.67-2.86,3.11-3.32$ (7m, 22H), $2.96(\mathrm{t}, J=8.7 \mathrm{~Hz}, 1 \mathrm{H}), 7.19-7.25,7.28-7.44(2 \mathrm{~m}, 5 \mathrm{H}) ;{ }^{13} \mathrm{C} \mathrm{NMR}\left(101 \mathrm{MHz}, \mathrm{CDCl}_{3}\right) \delta 24.7,24.8$, 25.6, 26.3, 26.6, 31.7, 51.7, 52.9, 65.3, 68.9, 70.2, 126.8, 127.4, 128.4, 143.8; MS (EI) m/z 284 (M+ , 9), 
201 (13), 174 (10), 173 (76), 172 (100), 110 (44); HRMS (ESI) m/z: [M + H] Calcd for $\mathrm{C}_{19} \mathrm{H}_{29} \mathrm{~N}_{2}$ 285.2341; Found 285.2331.

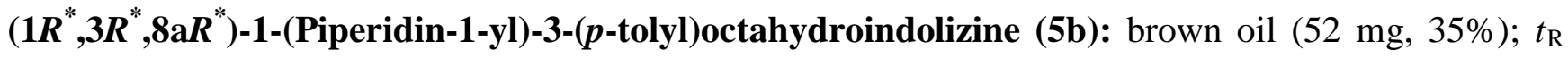
13.14; $R_{f} 0.40$ (hexane/EtOAc, 1:1); IR (neat) $v$ 3046, 3009, 2927, 2851, 2786, 2747, 1512, 1439, 1260, 1143, 1126, 1105, 1036, 863, 813, 797, 735; ${ }^{1} \mathrm{H}$ NMR (300 MHz, $\left.\mathrm{CDCl}_{3}\right) \delta 1.15-1.86(\mathrm{~m}, 14 \mathrm{H})$, 1.92-2.08 (m, 2H), 2.27-2.40 (m, 5H), 2.63-2.86 (m, 3H), $2.92(\mathrm{t}, J=8.7 \mathrm{~Hz}, 1 \mathrm{H}), 3.16(\mathrm{ddd}, \mathrm{m}, J=$ 9.0 Hz, 7.4, 3.8, 1H), 7.12 (d, $J=7.8 \mathrm{~Hz}, 2 \mathrm{H}), 7.23(\mathrm{~d}, J=7.8 \mathrm{~Hz}, 2 \mathrm{H}) ;{ }^{13} \mathrm{C} \mathrm{NMR}\left(75 \mathrm{MHz}, \mathrm{CDCl}_{3}\right) \delta$ 21.2, 24.8, 24.9, 25.6, 26.4, 26.6, 31.7, 51.8, 52.9, 65.4, 69.0, 70.0, 127.3, 129.1, 136.3, 140.9; MS (EI) m/z 298 (M+, 6), 215 (12), 188 (10), 187 (71), 186 (100), 110 (45); HRMS (ESI) m/z: [M + H] Calcd for $\mathrm{C}_{20} \mathrm{H}_{31} \mathrm{~N}_{2}$ 299.2487; Found 299.2500.

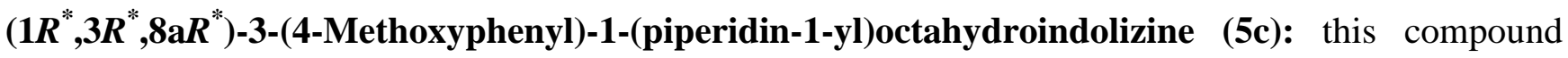
was isolated together with an inseparable impurity as a brown oil (71 mg, aprox. 45\%); $t_{\mathrm{R}} 14.20 ; R_{f}$ 0.42 (hexane/EtOAc, 4:6); IR (neat) v 3060, 2991, 2930, 2852, 2785, 2749, 1611, 1509, 1439, 1300, 1242, 1179, 1170, 1143, 1126, 1101, 1036, 828, 798; Selected NMR data: ${ }^{1} \mathrm{H}$ NMR (400 MHz, $\left.\mathrm{CDCl}_{3}\right)$

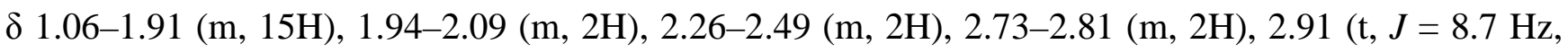
1H), 3.12-3.30 (m, 1H), 3.80 (s, 3H), 6.84-6.89 (m, 2H), 7.21-7.32 (m, 2H); ${ }^{13} \mathrm{CNMR}(101 \mathrm{MHz}$, $\left.\mathrm{CDCl}_{3}\right) \delta 24.7,24.8,25.6,26.2,26.6,31.7,51.7,52.8,55.4,65.2,68.9,69.7,113.8,128.4,135.8$, 158.6; MS (EI) m/z 314 (M+, 6), 231 (15), 204 (11), 203 (76), 202 (100), 110 (47); HRMS (ESI) m/z: $[\mathrm{M}+\mathrm{H}]^{+}$Calcd for $\mathrm{C}_{20} \mathrm{H}_{31} \mathrm{~N}_{2} \mathrm{O}$ 315.2436; Found 315.2435.

4-[(1 $\left.\left.{ }^{*}, 3 R^{*}, 8 \mathrm{a} \boldsymbol{R}^{*}\right)-3-P h e n y l o c t a h y d r o i n d o l i z i n-1-y l\right]$ morpholine (5d): yellow solid (97 mg, 68\%); $t_{\mathrm{R}}$ 12.69; $R_{f} 0.34$ (hexane/EtOAc, 8:2); mp 53.7-55.7 ${ }^{\circ} \mathrm{C}$ (EtOH); IR (neat) $v$ 3079, 3060, 3030, 2939, 2849, 2802, 2749, 1603, 1448, 1258, 1136, 1114, 998, 866, 755, 699; ${ }^{1} \mathrm{H}$ NMR (300 MHz, $\left.\mathrm{CDCl}_{3}\right) \delta$ 
1.16-1.28, 1.34-1.38, 1.50-1.69, 1.71-1.88, 2.00-2.12, 2.31-2.51, 2.73-2.91 (7m, 15H; $\left.7 \times \mathrm{CH}_{2}, \mathrm{CH}\right)$, 2.30 (t, $J=8.7 \mathrm{~Hz}, 1 \mathrm{H} ; \mathrm{CH}), 3.06-3.23(\mathrm{~m}, 1 \mathrm{H} ; \mathrm{CH}), 3.66-3.77\left(\mathrm{~m}, 4 \mathrm{H} ; 2 \times \mathrm{CH}_{2}\right), 7.21-7.36$ (m, $5 \mathrm{H} ; 5$ $\times \mathrm{ArH}) ;{ }^{13} \mathrm{C} \mathrm{NMR}\left(75 \mathrm{MHz}, \mathrm{CDCl}_{3}\right) \delta$ 24.6, 25.6, 26.7, 31.8, 51.1, 52.9, $67.4\left(9 \times \mathrm{CH}_{2}\right), 65.1,68.9$, 70.2 (3 × CH), 126.9, 127.3, 128.5 (5 × ArCH), 143.5 (ArC); MS (EI) m/z $286\left(\mathrm{M}^{+}, 3\right), 203$ (14), 173 (71), 172 (100), 112 (41), 104 (10); Anal. Calcd for $\mathrm{C}_{18} \mathrm{H}_{26} \mathrm{~N}_{2} \mathrm{O}$ : C, 75.48; H, 9.15; N, 9.78. Found: C, 75.88; H, 9.28; N 9.94.

$\left(1 R^{*}, 3 R^{*}, 8 \mathrm{a} R^{*}\right)-N$-Benzyl- $N$-methyl-3-phenyloctahydroindolizin-1-amine (5e): brown oil; $t_{\mathrm{R}} 14.14$ (96 mg, 60\%); $R_{f} 0.57$ (hexane/EtOAc, 8:2); IR (neat) v 3084, 3065, 3025, 2934, 2858, 2784, 1599, 1492, 1449, 1361, 1262, 1147, 1099, 1071, 1019, 867, 755, 731, 697; ${ }^{1} \mathrm{H}$ NMR (400 MHz, $\left.\mathrm{CDCl}_{3}\right) \delta$ $1.14-1.27,1.36-1.48,1.49-1.61,1.69-1.80,1.81-1.95,2.10-2.19$ (6m, 10H), 2.33 (s, 3H), 2.84 (d, $J=$ $10.6 \mathrm{~Hz}, 1 \mathrm{H}), 3.02$ (t, $J=8.7 \mathrm{~Hz}, 1 \mathrm{H}), 3.34-3.47$ (d, m, $J=13.8 \mathrm{~Hz}, 2 \mathrm{H}), 4.10$ (d, $J=13.8 \mathrm{~Hz}, 1 \mathrm{H})$, 7.22-7.26, 7.28-7.40 (2m, 10H); ${ }^{13} \mathrm{C}$ NMR (101 MHz, $\left.\mathrm{CDCl}_{3}\right) \delta$ 24.8, 25.5, 26.7, 32.1, 52.8, 59.0, 39.9, 63.1, 69.0, 70.1, 126.9, 127.0, 127.4, 128.4, 128.5, 128.9, 139.4, 143.5; MS (EI) m/z $320\left(\mathrm{M}^{+}, 2\right)$, 237 (13), 173 (76), 172 (100), 146 (46), 91 (35); HRMS (ESI) m/z: [M + H] Calcd for $\mathrm{C}_{22} \mathrm{H}_{29} \mathrm{~N}_{2}$ 321.2335; Found 321.2331.

$\left(1 R^{*}, 3 R^{*}, 8 \mathrm{a} R^{*}\right)-N$-Methyl- $N$-phenethyl-3-phenyloctahydroindolizin-1-amine (5f): brown oil; $t_{\mathrm{R}}$ 15.50 (102 mg, 61\%); $R_{f} 0.66$ (hexane/EtOAc, 4:6); IR (neat) v 3084, 3065, 3025, 2933, 2848, 2784, 2749, 1603, 1493, 1451, 1362, 1262, 1144, 1100, 1029, 934, 867, 802, 755, 697; ${ }^{1} \mathrm{H}$ NMR (300 MHz, $\left.\mathrm{CDCl}_{3}\right) \delta$ 1.19-1.89, 2.04-2.18 (2m, 10H), 2.42 (s, 3H), 2.44-2.63, 2.73-2.85, 2.94-3.11, 3.25-3.42 (4m, 7H), 7.15-7.36 (m, 10H); ${ }^{13} \mathrm{C}$ NMR (101 MHz, $\left.\mathrm{CDCl}_{3}\right) \delta$ 24.8, 25.7, 26.9, 32.8, 35.0, 52.8, 57.2, 40.1, 64.1, 69.2, 70.1, 125.9, 126.9, 127.4, 128.3, 128.4, 128.9, 141.1, 143.6; MS (EI) m/z $334\left(\mathrm{M}^{+}, 1\right)$, 251 (11), 243 (39), 173 (70), 172 (100), 160 (42), 139 (10), 91 (11); HRMS (ESI) m/z: [M + H] Calcd for $\mathrm{C}_{23} \mathrm{H}_{31} \mathrm{~N}_{2}$ 335.2487; Found 335.2490. 
$\left(1 R^{*}, 3 R^{*}, 8 a R^{*}\right)-N, N$-Dibutyl-3-phenyloctahydroindolizin-1-amine (5g): brown oil (108 $\left.\mathrm{mg}, 66 \%\right)$; $t_{\mathrm{R}}$ 12.74; $R_{f} 0.54$ (hexane/EtOAc, 8:2); IR (neat) $v$ 3060, 3025, 2936, 2852, 2792, 1601, 1492, 1451, 1363, 1263, 1145, 1027, 976, 755, 741, 731, 696; ${ }^{1} \mathrm{H}$ NMR (300 MHz, $\left.\mathrm{CDCl}_{3}\right) \delta 0.92$ (t, $J=7.2 \mathrm{~Hz}$, 6H), 1.14-1.87, 2.01-2.15, 2.18-2.36, 2.75-2.86, (4m, 23H), 2.94 (t, $J=8.7 \mathrm{~Hz}, 1 \mathrm{H}), 3.29-3.45$ (m, 1H), 7.19-7.25 (m, 1H), 7.28-7.38 (m, 4H); ${ }^{13} \mathrm{C}$ NMR (75 MHz, $\left.\mathrm{CDCl}_{3}\right) \delta$ 14.4, 20.9, 25.0, 25.8, 27.1, 31.1, 34.1, 52.2, 52.8, 60.7, 69.5, 70.3, 126.8, 127.5, 128.4, 144.0; MS (EI) m/z 328 (M+1 4), 174 (10), 173 (84), 172 (100), 154 (40), 140 (10), 117 (10), 91 (11); HRMS (ESI) m/z: [M + H] Calcd for $\mathrm{C}_{22} \mathrm{H}_{37} \mathrm{~N}_{2}$ 329.2961; Found 329.2957.

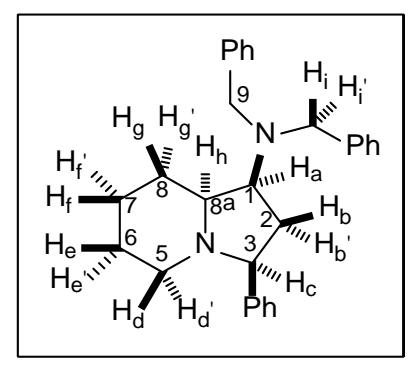

$\left(1 R^{*}, 3 R^{*}, 8 \mathrm{a} R^{*}\right)-N, N$-Dibenzyl-3-phenyloctahydroindolizin-1-amine (5h): brown oil (129 mg, 65\%); $t_{\mathrm{R}} 21.06 ; R_{f} 0.89$ (hexane/EtOAc, 8:2); IR $v$ 3060, 3025, 2936, 2852, 2792, 1601, 1492, 1451, 1363, 1263, 1145, 1027, 976, 755, 741, 731, 696; ${ }^{1} \mathrm{HNMR}\left(300 \mathrm{MHz}, \mathrm{CDCl}_{3}\right) \delta 1.14-1.25\left(\mathrm{~m}, 1 \mathrm{H} ; \mathrm{H}_{\mathrm{f}}\right.$ ), 1.34-1.44 (m, 1H; $\left.\mathrm{H}_{\mathrm{e}^{\prime}}\right), 1.46-1.59$ (m, 2H; $\left.\mathrm{H}_{\mathrm{e}}, \mathrm{H}_{\mathrm{d}^{\prime}}\right), 1.75-1.87$ (m, 3H; $\left.\mathrm{H}_{\mathrm{b}}, \mathrm{H}_{\mathrm{f}^{\prime}}, \mathrm{H}_{\mathrm{g}}\right), 1.88-1.95$ (m, 1H; $\mathrm{H}_{\mathrm{g}}$ ), 1.99-2.08 (m, 1H; $\mathrm{H}_{\mathrm{h}}$ ), 2.08-2.19 (m, 1H; $\mathrm{H}_{\mathrm{b}^{\prime}}$ ), 2.81 (d, $\left.J=10.4 \mathrm{~Hz}, 1 \mathrm{H} ; \mathrm{H}_{\mathrm{d}}\right), 2.98(\mathrm{t}, J=8.8$ $\mathrm{Hz}, 1 \mathrm{H} ; \mathrm{H}_{\mathrm{c}}$ ), $3.28\left(\mathrm{~d}, J=14.8 \mathrm{~Hz}, 2 \mathrm{H} ; 2 \times \mathrm{H}_{\mathrm{i}}\right.$ ), 3.36 (td, $J=8.8,4.0 \mathrm{~Hz}, 1 \mathrm{H} ; \mathrm{H}_{\mathrm{a}}$ ), 4.20 (br s, $2 \mathrm{H} ; 2 \times$ $\left.\mathrm{H}_{\mathrm{i}}{ }^{\prime}\right), 7.19-7.27(\mathrm{~m}, 3 \mathrm{H} ; 3 \times \mathrm{ArH}), 7.28-7.40(\mathrm{~m}, 8 \mathrm{H} ; 8 \times \mathrm{ArH}), 7.41-7.51(\mathrm{~m}, 4 \mathrm{H} ; 4 \times \mathrm{ArH}) ;{ }^{13} \mathrm{C} \mathrm{NMR}$ (75 MHz, CDCl 3 ) $\delta 24.8$ (C-6), 25.6 (C-7), 27.0 (C-8), 32.4 (C-2), 52.9 (C-5), 56.1 (2 × C-9), 58.5 (C1), 69.1 (C-8a), 70.2 (C-3), 126.7, 126.9, 127.4, 128.4, 128.5 (15 × ArCH), 140.8, 143.7 (3 × ArC); MS (EI) m/z 396 (M+1, 0.3), 306 (14), 305 (59), 222 (51), 174 (10), 173 (79), 172 (100), 117 (12), 91 (72); HRMS (ESI) m/z: [M + H] $]^{+}$Calcd for $\mathrm{C}_{28} \mathrm{H}_{32} \mathrm{~N}_{2}$ 396.2565; Found 396.2585.

$\left(1 R^{*}, 3 R^{*}, 8 \mathrm{a} R^{*}\right)-N, N$-Dibenzyl-3-( $p$-tolyl)octahydroindolizin-1-amine (5i): brown oil (119 mg, 58\%); $t_{\mathrm{R}}$ 22.80; $R_{f} 0.86$ (hexane/EtOAc, 8:2); IR (neat) $v$ 3079, 3060, 3030, 2935, 2858, 2794, 2754, 1603, 1493, 1451, 1362, 1263, 1145, 813, 770, 740, 728, 696; ${ }^{1} \mathrm{H}$ NMR (400 MHz, $\left.\mathrm{CDCl}_{3}\right) \delta$ 1.14-1.56, 
1.75-1.96, 1.99-2.16 (3 m, 10H), 2.35 (s, 3H), 2.80 (d, J = 10.6 Hz, 1H), 2.94 (t, J= 8.7 Hz, 1H), 3.28 (d, $J=14.5 \mathrm{~Hz}, 2 \mathrm{H}), 3.31-3.40$ (m, 1H), 4.19 (broad s, 2H), 7.12-7.16, 7.19-7.25, 7.25-7.34, 7.41$7.53(4 \mathrm{~m}, 14 \mathrm{H}) ;{ }^{13} \mathrm{C}$ NMR (101 $\left.\mathrm{MHz} \mathrm{CDCl}_{3}\right) \delta$ 21.3, 24.8, 25.6, 27.0, 32.4, 52.9, 56.1, 58.5, 69.1, 69.9, 126.7, 127.3, 128.3, 128.5, 129.2, 136.5, 140.7, 140.8; MS (EI) m/z 410 (M+1, 0.2), 320 (10), 319 (41), 236 (31), 222 (10), 188 (11), 187 (77), 186 (97), 131 (12), 118 (14), 117 (11), 106 (10), 105 (27), 91 (100); HRMS (ESI) m/z: [M + H] $]^{+}$Calcd for $\mathrm{C}_{29} \mathrm{H}_{35} \mathrm{~N}_{2}$ 411.2800; Found 411.2813.

$\left(1 R^{*}, 3 R^{*}, 8 \mathrm{a} R^{*}\right)-N, N$-Dibenzyl-3-(4-methoxyphenyl)octahydroindolizin-1-amine $(5 \mathrm{j}):$ brown oil (183 mg, 86\%); $t_{\mathrm{R}}$ 31.39; $R_{f} 0.26$ (hexane/EtOAc, 8:2); IR (neat) $v$ 3060, 3025, 2934, 2851, 2832, 2791, 2752, 1610, 1509, 1242, 1170, 1145, 1101, 1036, 828, 740, 728, 697; ${ }^{1} \mathrm{H}$ NMR (300 MHz, $\left.\mathrm{CDCl}_{3}\right) \delta 1.11-1.55,1.76-2.15$ (2m, 10H), 2.79 (d, $\left.J=10.4 \mathrm{~Hz}, 1 \mathrm{H}\right), 2.91$ (t, $\left.J=8.7 \mathrm{~Hz}, 1 \mathrm{H}\right), 3.20$ 3.43 (d, m, J= 14.4 Hz, 3H), 3.81 (s, 3H), 3.93-4.45 (m, 2H), 6.86-6.92, 7.18-7.26, 7.28-7.36, 7.427.54 (4m, 14H); ${ }^{13} \mathrm{C}$ NMR (75 MHz, $\left.\mathrm{CDCl}_{3}\right) \delta$ 24.9, 25.6, 27.0, 32.3, 52.8, 56.1, 55.4, 58.4, 69.1, 69.6, 113.9, 126.7, 128.3, 128.4, 128.5, 135.7, 140.8, 158.7; MS (EI) m/z 426 (M+ 0.3), 343 (10), 336 (18), 335 (74), 252 (35), 222 (23), 204 (13), 203 (91), 202 (100), 134 (10), 121 (47), 91 (75); HRMS (ESI) m/z: $[\mathrm{M}+\mathrm{H}]^{+}$Calcd for $\mathrm{C}_{29} \mathrm{H}_{35} \mathrm{~N}_{2} \mathrm{O}$ 427.2749; Found 427.2763.

Methyl 4-[(1 $\left.R^{*}, 3 R^{*}, 8 \mathrm{a} R^{*}\right)-1-($ dibenzylamino)octahydroindolizin-3-yl)]benzoate (5k): white solid (216 mg, 95\%); $R_{f} 0.60$ (hexane/EtOAc, 8:2); mp 144.5-147.6; IR (neat) $v$ 3058, 2945, 2792, 1719, 1274, 1110, 1097, 769, 733, 697; ${ }^{1} \mathrm{H}$ NMR (300 MHz, $\mathrm{CDCl}_{3}$ ) $\delta$ 1.16-1.61 (m, 4H), 1.76-1.95 (m, 4H), 2.04-2.19 (m, 2H), 2.79 (d, $J=10.7 \mathrm{~Hz}, 1 \mathrm{H}), 3.06$ (t, $J=8.7 \mathrm{~Hz}, 1 \mathrm{H}), 3.24$ (d, $J=14.4 \mathrm{~Hz}, 2 \mathrm{H})$, 3.39 (td, $J=8.7,3.9 \mathrm{~Hz}, 1 \mathrm{H}), 3.92$ (s, 3H), 4.17 (br s, 2H), 7.23 (t, $J=7.3 \mathrm{~Hz}, 2 \mathrm{H}), 7.32$ (t, $J=7.5 \mathrm{~Hz}$, 4H), 7.45 (m, 6H), 8.02 (m, 2H); $\left.{ }^{13} \mathrm{C} \mathrm{NMR} \mathrm{(75} \mathrm{MHz,} \mathrm{CDCl}_{3}\right) \delta$ 24.6, 25.4, 26.8, 32.1, 52.0, 52.8, 55.8, 58.5, 69.0, 69.6, 126.6, 127.1, 128.2, 128.3, 129.8, 128.7, 140.4, 149.2, 167.1; MS (EI) m/z $454\left(\mathrm{M}^{+}\right.$, 
0.4), 364 (18), 363 (72), 281 (13), 280 (65), 232 (14), 231 (100), 230 (96), 222 (10), 216 (20), 91 (70); Anal. Calcd for $\mathrm{C}_{30} \mathrm{H}_{34} \mathrm{~N}_{2} \mathrm{O}_{2}$ : C, 79.26; H, 7.54; N, 6.16. Found: C, 78.80; H, 7.48; N, 6.11.

$\left(1 R^{*}, 3 R^{*}, 8 \mathrm{a} R^{*}\right)-N, N$-Dibenzyl-3-[4-(trifluoromethyl)phenyl]octahydroindolizin-1-amine (5l): beige solid (128 mg, 55\%); $t_{\mathrm{R}}$ 19.28; $R_{f} 0.80$ (hexane/EtOAc, 7:3); mp 141.6-144.4 ${ }^{\circ} \mathrm{C}$; IR (neat) $v$ 3079, 3060, 3030, 2937, 2853, 2792, 2754, 1617, 1322, 1161, 1121, 1102, 1066, 1018, 834, 739, 729, 697;

${ }^{1} \mathrm{H}$ NMR (300 MHz, $\mathrm{CDCl}_{3}$ ) $\delta$ 1.13-1.64, 1.74-1.99, 2.05-2.22 (3m, 10H), 2.79 (d, $\left.J=10.5 \mathrm{~Hz}, 1 \mathrm{H}\right)$, 3.06 (t, $J=8.7 \mathrm{~Hz}, 1 \mathrm{H}), 3.24$ (d, $J=14.4 \mathrm{~Hz}, 2 \mathrm{H}), 3.32-3.49$ (m, 1H), 3.97-4.42 (m, 2H), 7.20-7.26, 7.29-7.36, 7.43-7.52, 7.58-7.63 (4m, 14H); $\left.{ }^{13} \mathrm{C} \mathrm{NMR} \mathrm{(75} \mathrm{MHz,} \mathrm{CDCl}_{3}\right) \delta$ 24.7, 25.5, 27.0, 32.3, 52.9, 56.0, 58.6, 69.1, 69.7, $124.4\left(\mathrm{q},{ }^{1} J_{\mathrm{C}-\mathrm{F}}=271.9 \mathrm{~Hz}\right), 125.5\left(\mathrm{q},{ }^{3} J_{\mathrm{C}-\mathrm{F}}=3.8 \mathrm{~Hz}\right), 126.8,127.6,128.4,128.5$, $129.1\left(\mathrm{q},{ }^{2} J_{\mathrm{C}-\mathrm{F}}=32.1 \mathrm{~Hz}\right), 140.5,148.0$; MS (EI) m/z $464\left(\mathrm{M}^{+}, 0.1\right), 373$ (39), 291 (10), 290 (54), 242 (11), 241 (78), 240 (100), 172 (11), 91 (82); Anal. Calcd for $\mathrm{C}_{29} \mathrm{H}_{31} \mathrm{~F}_{3} \mathrm{~N}_{2}$ : C, 74.98; H, 6.73; N, 6.03. Found: C, 74.95; H, 6.75; N, 5.90.

$\left(1 R^{*}, 3 S^{*}, 8 \mathrm{a} R^{*}\right)-N, N$-Dibenzyl-3-decyloctahydroindolizin-1-amine (5m): brown oil (166 mg, 72\%); $t_{\mathrm{R}}$ 25.57; $R_{f} 0.83$ (hexane/EtOAc, 7:3); IR v 3079, 3060, 3020, 2922, 2852, 2791, 2754, 1603, 1493, 1452, 1364, 1263, 1148, 1027, 981, 938, 771, 733, 696; ${ }^{1} \mathrm{H}$ NMR $\left(300 \mathrm{MHz}, \mathrm{CDCl}_{3}\right) \delta 0.89(\mathrm{t}, J=6.7$ Hz, 3H), 1.07-1.45, 1.47-1.89 (2m, 29H), 3.08-3.16, 3.17-3.25 (2m, 2H), 3.29 (d, J = 14.6 Hz, 2H), 3.84-4.29 (m, 2H), 7.17-7.23, 7.26-7.33, 7.39-7.50 (3m, 10H); $\left.{ }^{13} \mathrm{C} \mathrm{NMR} \mathrm{(75} \mathrm{MHz,} \mathrm{CDCl}_{3}\right) \delta 14.3$, 22.9, 25.1, 25.7, 26.8, 27.0, 28.0, 29.5, 29.8, 29.9, 30.3, 32.1, 32.8, 53.0, 56.1, 58.0, 65.6, 69.8, 126.6, 128.3, 128.4, 140.9; MS (EI) m/z 460 (M+1, 0.4), 370 (20), 369 (71), 238 (18), 237 (100), 236 (50), 166 (12), 138 (12), 124 (42), 122 (18), 111 (17), 110 (51), 98 (11), 97 (21), 96 (13), 91 (72), 84 (12); Anal. Calcd for $\mathrm{C}_{32} \mathrm{H}_{48} \mathrm{~N}_{2}$ : C, 83.42; H, 10.50; N, 6.08. Found: C, 83.81; H, 10.23; N, 5.73. 
$\left(1 R^{*}, 3 R^{*}, 8 \mathrm{a} R^{*}\right)-N, N$-Dibutyl-1-phenyl-1,2,3,3a,4,5-hexahydropyrrolo[1,2-a]quinolin-3-amine (5n): yellow oil (85 mg, 45\%), $t_{\mathrm{R}}$ 21.37; $R_{f}$ 0.75(hexane/EtOAc, 9:1); IR (neat) $v$ 3021, 2957, 2921, 2856, 2816, 1598, 1491, 1455, 1320, 1097, 1079, 1029, 803, 751, 703; ${ }^{1} \mathrm{H}$ NMR $\left(300 \mathrm{MHz}, \mathrm{CDCl}_{3}\right) \delta 0.87(\mathrm{t}$, $\left.J=7.2 \mathrm{~Hz}, 6 \mathrm{H} ; 2 \times \mathrm{CH}_{3}\right), 1.14-1.43\left(\mathrm{~m}, 8 \mathrm{H} ; 4 \times \mathrm{CH}_{2}\right), 1.94(\mathrm{ddd}, J=14.0,6.5,3.6 \mathrm{~Hz}, 1 \mathrm{H} ; \mathrm{CH})$, 2.06-2.19 (m, 4H; $\left.2 \times \mathrm{CH}_{2}\right), 2.52-2.65$ (m, 3H), 2.92-3.00 (m, 2H), 3.36-3.52 (m, 2H), 4.35 (dd, $J=$ 9.8, $6.5 \mathrm{~Hz}, 1 \mathrm{H} ; \mathrm{CH}), 6.14$ (dd, $J=8.1,0.9 \mathrm{~Hz}, 1 \mathrm{H}$; ArH), 6.64 (td, $J=7.3,1.1 \mathrm{~Hz}, 1 \mathrm{H}$; ArH), 6.79 (td, $J=8.2,1.7 \mathrm{~Hz}, 1 \mathrm{H} ; \mathrm{ArH}), 7.05$ (dd, $J=7.4,1.2 \mathrm{~Hz}, 1 \mathrm{H} ; \mathrm{ArH}), 7.17-7.29$ (m, 5H; ArH); ${ }^{13} \mathrm{C}$ NMR (75 $\left.\mathrm{MHz}, \mathrm{CDCl}_{3}\right) \delta 14.2\left(2 \times \mathrm{CH}_{3}\right), 20.6,24.5,27.9,30.3,36.1,51.8\left(9 \times \mathrm{CH}_{2}\right), 60.7,63.2,64.2(3 \times \mathrm{CH})$, 114.9, 117.9, 125.9, 126.3, 128.1, 128.3, 128.7 (9 × ArCH), 125.6, 144.0, 146.9 (3 × ArC); MS (EI) m/z 376 (M+1 18), 329 (9), 247 (11), 246 (12), 245 (20), 244 (30), 221 (55), 220 (100), 202 (20), 155 (11), 154 (72), 117 (25), 115 (12), 91 (11); HRMS (ESI) m/z: [M+] Calcd for $\mathrm{C}_{26} \mathrm{H}_{36} \mathrm{~N}_{2}$ 376.2878; Found 376.2889.

$\left(1 R^{*}, 3 R^{*}, 5 R^{*}, 8 \mathrm{a} R^{*}\right)-N, N$-Dibenzyl-5-methyl-3-phenyloctahydroindolizin-1-amine (5o): yellow oil (82 mg, 40\%), $t_{\mathrm{R}}$ 28.22; $R_{f} 0.83$ (hexane/EtOAc, 8:2); IR (neat) v 3027, 2926, 2849, 2797, 1492, 1452, 1140, 993, 732, 697, 617; ${ }^{1} \mathrm{H}$ NMR (300 MHz, $\left.\mathrm{CDCl}_{3}\right) \delta 0.54$ (d, $\left.J=6.4 \mathrm{~Hz}, 3 \mathrm{H}\right), 1.18-1.44$ (m, 5H), 1.72-1.95 (m, 5H), 2.14-2.25 (m, 2H), 3.21 (d, $\left.J=14.2 \mathrm{~Hz}, 2 \mathrm{H} ; \mathrm{CH}_{2}\right), 3.23$ (t, $\left.J=4.4 \mathrm{~Hz}, 1 \mathrm{H}\right), 3.28$ (ddd, $J=9.5,7.9,3.6 \mathrm{~Hz}, 1 \mathrm{H}), 4.23$ (d, $J=14.2 \mathrm{~Hz}, 2 \mathrm{H} ; \mathrm{CH}_{2}$ ), 7.18-7.25 (m, 3H; $3 \times$ ArH), 7.29-7.34 $(\mathrm{m}, J=7.5 \mathrm{~Hz}, 8 \mathrm{H} ; 8 \times \mathrm{ArH}), 7.46(\mathrm{~d}, J=7.5 \mathrm{~Hz}, 4 \mathrm{H} ; 4 \times \mathrm{ArH}) ;{ }^{13} \mathrm{C} \mathrm{NMR}\left(75 \mathrm{MHz}, \mathrm{CDCl}_{3}\right) \delta 23.3$ $\left(\mathrm{CH}_{3}\right), 25.3,27.3,34.2,35.6\left(4 \times \mathrm{CH}_{2}\right), 55.9\left(2 \times \mathrm{CH}_{2} \mathrm{~N}\right), 58.5,62.9,69.8,70.8(4 \times \mathrm{CH}), 126.2$, 126.6, 126.7, 128.1, 128.4 (15 × ArCH), 140.1, 148.0 (3 × ArC); MS (EI) m/z 319 (73), 222 (49), 207 (20), 187 (64), 186 (89), 117 (14), 106 (10), 104 (12), 92 (11), 91 (100); HRMS (ESI) m/z: [M+1 Calcd for $\mathrm{C}_{29} \mathrm{H}_{34} \mathrm{~N}_{2}$ 410.2722, [M - Bn] 319.2174; Found 319.2195. 
General procedure for the hydrogenolysis of indolizines 5 to monobenzylated indolizidines 6: The indolizine 5 (0.3 mmol) was poured into the hydrogenation flask, followed by the addition of $\operatorname{Pt}(5$ wt\%)/C (117 mg, 10 mol\%) or $\mathrm{PtO}_{2}$ (11.4 mg, 10 mol\%) and glacial HOAc (3 mL), with this mixture being subjected to hydrogenation at ca. 1 atm (balloon) and ambient temperature. The reaction was monitored by TLC and/or GLC until total or steady conversion of the starting material (see Table 3). The catalyst was separated by filtration and the glacial HOAc was neutralized with $2 \mathrm{M} \mathrm{NaOH}$, followed by extraction with EtOAc, drying of the organic phase with $\mathrm{Na}_{2} \mathrm{SO}_{4}$ and solvent evaporation under vacuum. Purification of the reaction crude by preparative TLC (silica gel, hexane/EtOAc 6:4) afforded the pure indolizidines $\mathbf{6}$ as single diastereoisomers.

$\left(1 R^{*}, 3 R^{*}, 8 \mathrm{a} \boldsymbol{R}^{*}\right)-N$-Benzyl-3-phenyloctahydroindolizin-1-amine (6h): brown oil (63 mg, 68\%); $t_{\mathrm{R}}$ 15.38; $R_{f} 0.44$ (hexane/EtOAc, 3:7); IR (neat) $v$ 3029, 2935, 2851, 2789, 1603, 1492, 1451, 1145 , 1117, 754, 731, 609; ${ }^{1} \mathrm{H}$ NMR (300 $\left.\mathrm{MHz} \mathrm{CDCl}_{3}\right) \delta 1.15-1.31$ (m, 1H), 1.38-1.86 (m, 8H), 2.06-2.15 (m, 1H), 2.43 (dt, $J=13.5,8.0 \mathrm{~Hz}, 1 \mathrm{H}), 2.83$, (d, $J=10.7 \mathrm{~Hz}, 1 \mathrm{H}), 3.07$ (t, $J=8.4 \mathrm{~Hz}, 1 \mathrm{H}$ ), 3.14 (ddd, $J=7.9,6.1,3.1 \mathrm{~Hz}, 1 \mathrm{H}), 3.68,3.86$ (AB system, $J=13.4 \mathrm{~Hz}, 2 \mathrm{H}), 7.20-7.37$ (m, 10H); ${ }^{13} \mathrm{C}$ NMR (75

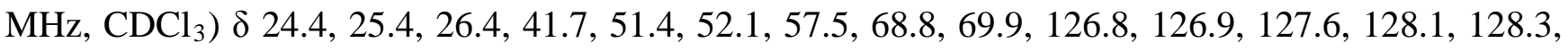
140.7, 143.3; MS (70 eV) m/z (\%) 306 (M+, 3), 223 (20), 197 (21), 196 (20), 173 (61), 172 (100), 168 (11), 132 (29), 91 (25); HRMS (EI) m/z: Calcd for $\mathrm{C}_{21} \mathrm{H}_{26} \mathrm{~N}_{2}$ 306.2096; Found 306.2092.

$\left(1 R^{*}, 3 R^{*}, 8 \mathrm{a} R^{*}\right)-N$-Benzyl-3-(4-methoxyphenyl)octahydroindolizin-1-amine (6j): brown oil; (73 mg, $72 \%) ; t_{\mathrm{R}} 18.52 ; R_{f} 0.13$ (hexane/EtOAc, 6:4); IR (neat) $v$ 3060, 2951, 2851, 1509, 1426, 1301, 1259, 1112, 896, 734, 698; ${ }^{1} \mathrm{H}$ NMR (300 MHz, $\mathrm{CDCl}_{3}$ ) $\delta$ 1.19-1.92 (m, 9H), 2.02-2.13 (m, 1H), 2.41 (dt, $J$ = 13.5, $8.0 \mathrm{~Hz}, 1 \mathrm{H}), 2.81(\mathrm{~d}, J=10.7 \mathrm{~Hz}, 1 \mathrm{H}), 3.02$ (t, $J=8.4 \mathrm{~Hz}, 1 \mathrm{H}), 3.14$ (ddd, $J=7.8,6.1,3.1 \mathrm{~Hz}$, 1H), 3.69, 3.87 (AB system, $J=13.4 \mathrm{~Hz}, 2 \mathrm{H}), 3.80$ (s, 3H), 6.86 (d, $J=8.4 \mathrm{~Hz}, 2 \mathrm{H}), 7.21-7.36$ (m, 7H); ${ }^{13} \mathrm{C}$ NMR $\left(75 \mathrm{MHz}, \mathrm{CDCl}_{3}\right) \delta$ 24.3, 25.3, 26.3, 41.6, 51.4, 52.0, 55.2, 57.4, 68.8, 69.4, 113.7, 
126.8, 128.1, 128.3, 128.7, 135.0, 140.6, 158.6; MS (70 eV) m/z (\%) 336 (M+, 2), 253 (21), 252 (10), 231 (10), 227 (39), 226 (13), 212 (17), 207 (13), 203 (58), 202 (100), 162 (34), 135 (12), 134 (20), 132 (39), 106 (16), 92 (10), 91 (66), 84 (12), 77 (14), 65 (10); HRMS (EI) m/z: Calcd for $\mathrm{C}_{22} \mathrm{H}_{28} \mathrm{~N}_{2} \mathrm{O}$ 336.2202; Found 336.2185.

$\left(1 R^{*}, 3 R^{*}, 8 \mathrm{a} R^{*}\right)-N$-Benzyl-3-[4-(trifluoromethyl)phenyl]octahydroindolizin-1-amine (6l): brown oil (73 mg, 65\%); $t_{\mathrm{R}}$ 15.06; $R_{f} 0.48$ (hexane/EtOAc, 6:4); IR (neat) $v$ 3029, 2934, 2852, 2789, 2753, 1509, 1325, 1162, 1119, 1018, 837, 731, 697; ${ }^{1} \mathrm{H}$ NMR (300 MHz, $\mathrm{CDCl}_{3}$ ) $\delta$ 1.08-1.99 (m, 9H), 2.07-2.29 (m, 1H), 2.34-2.61 (m, 1H), 2.80 (d, $J=10.7 \mathrm{~Hz}, 1 \mathrm{H}), 3.08-3.21(\mathrm{~m}, 2 \mathrm{H}), 3.67,3.84$ (AB system, $J=$ 13.3 Hz, 2H), 7.20-7.35 (m, 5H), 7.47, 7.56 (AA’BB’system, $J=8.2 \mathrm{~Hz}, 4 \mathrm{H})$; ${ }^{13} \mathrm{C}$ NMR $(75 \mathrm{MHz}$, $\left.\mathrm{CDCl}_{3}\right) \delta 24.2,25.3,26.4,41.8,51.5,52.1,57.7,68.7,69.3,124.3(\mathrm{q}, J=271.8 \mathrm{~Hz}) 125.3(\mathrm{q}, J=3.7$ Hz), 126.8, 127.8, 128.1, 128.3, 129.1 (q, $J=32.2 \mathrm{~Hz})$ 140.7, 147.9; MS (70 eV) m/z (\%) $374\left(\mathrm{M}^{+}, 2\right)$, 291 (8), 269 (11), 242 (10), 241 (62), 240 (100), 172 (11), 132 (20), 91 (38), 84 (27); HRMS (EI) m/z: Calcd for $\mathrm{C}_{22} \mathrm{H}_{25} \mathrm{~F}_{3} \mathrm{~N}_{2}$ 374.1970; Found 374.1967.

$\left(1 R^{*}, 3 R^{*}, 8 \mathrm{a} R^{*}\right)-N$-Benzyl-3-decyloctahydroindolizin-1-amine (6m): brown oil (90 mg, 81\%); $t_{\mathrm{R}}$ 19.19; $R_{f} 0.20$ (hexane/EtOAc, 3:7); IR (neat) $v$ 3029, 2922, 2852, 2817, 1566, 1454, 1145, 980, 743, 698; ${ }^{1} \mathrm{H}$ NMR (300 MHz, $\left.\mathrm{CDCl}_{3}\right) \delta 0.88(\mathrm{t}, J=6.7 \mathrm{~Hz}, 3 \mathrm{H}), 1.09-1.40$ (m, 20H), 1.43-2.04 (m, 9H), 2.2 (dt, $J=13.1,7.8 \mathrm{~Hz}, 1 \mathrm{H}), 2.96-3.07$ (m, 1H), 3.19 (d, $J=10.5 \mathrm{~Hz}, 1 \mathrm{H}), 3.65,3.84$ (AB system, $J=$ 13.4 Hz, 2H), 7.17-7.35 (m, 5H); ${ }^{13} \mathrm{C}$ NMR (75 MHz, $\left.\mathrm{CDCl}_{3}\right) \delta$ 14.1, 22.7, 24.6, 25.2, 26.2, 26.6, 29.3, 29.6, 30.0, 31.9, 38.0, 51.6, 52.2, 56.9, 65.3, 69.4, 126.6, 128.1, 128.2, 140.7; MS (70 eV) m/z (\%) 370 (M+, 3), 261 (9), 238 (13), 237 (49), 236 (23), 229 (28), 135 (14), 134 (100), 132 (12), 124 (27), 111 (10), 110 (27), 97 (11), 91 (25); HRMS (EI) m/z: Calcd for $\mathrm{C}_{25} \mathrm{H}_{42} \mathrm{~N}_{2}$ 370.3348; Found 370.3337. 
General procedure for the hydrogenolysis of indolizines 5 to debenzylated indolizidines 7: The indolizine 5 (0.3 mmol) was poured into the hydrogenation flask, followed by the addition of $\operatorname{Pd}(20$ wt\%)/C (16 mg, $10 \mathrm{~mol} \%)$ and glacial HOAc (3 mL), with this mixture being subjected to hydrogenation at ca. 1 atm (balloon) and ambient temperature. The reaction was monitored by TLC and/or GLC until total or steady conversion of the starting material (see Table 3). The catalyst was separated by filtration and the glacial HOAc was neutralized with $2 \mathrm{M} \mathrm{NaOH}$, followed by extraction with EtOAc, drying of the organic phase with $\mathrm{Na}_{2} \mathrm{SO}_{4}$ and solvent evaporation under vacuum. Compounds $\mathbf{7 j}$ and $\mathbf{7 m}$ did not require any further purification; compounds $\mathbf{7 h}$ and $\mathbf{7 l}$ were purified by preparative TLC (EtOAc). In all cases, the pure indolizidines 7 were obtained as single diastereoisomers.

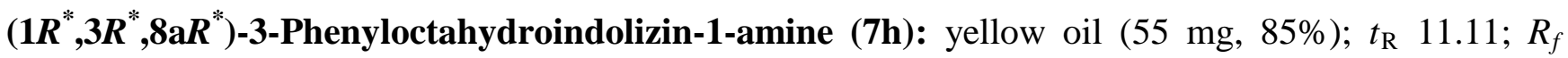
0.20 (EtOAc/MeOH, 8:2); IR (neat) v 3038, 2932, 2854, 1555, 1455, 1388, 1311, 1145, 754, 698; ${ }^{1} \mathrm{H}$ NMR (300 MHz, $\left.\mathrm{CDCl}_{3}\right) \delta 1.21-1.62(\mathrm{~m}, 6 \mathrm{H}), 1.63-1.88$ (m, 3H), 2.02 (ddd, $\left.J=7.5,5.4,2.7 \mathrm{~Hz}, 2 \mathrm{H}\right)$, 2.62 (ddd, $J=14.0,8.8,8.0 \mathrm{~Hz}, 1 \mathrm{H}), 2.83$ (d, $J=10.8 \mathrm{~Hz}, 1 \mathrm{H}), 3.07$ (t, $J=8.4 \mathrm{~Hz}, 1 \mathrm{H}), 3.27$ (ddd, $J=$ 7.7, 5.1, $2.4 \mathrm{~Hz}, 1 \mathrm{H}), 7.15-7.26(\mathrm{~m}, 1 \mathrm{H}), 7.28-7.36$ (m, 4H); ${ }^{13} \mathrm{C}$ NMR $\left(75 \mathrm{MHz}, \mathrm{CDCl}_{3}\right) \delta$ 23.9, 25.2, 26.0, 43.9, 51.7, 52.3, 68.6, 69.4, 126.8, 127.4, 128.2, 143.2; MS (70 eV) m/z (\%) $217\left(\mathrm{M}^{+}+1,1\right), 216$ (M+ $\mathrm{M}^{+}$), 173 (51), 172 (100), 132 (8), 104 (7), 84 (15); HRMS (EI) m/z: Calcd for $\mathrm{C}_{14} \mathrm{H}_{20} \mathrm{~N}_{2} 216.1626$, $\mathrm{C}_{14} \mathrm{H}_{17} \mathrm{~N}\left[\mathrm{M}^{+}-\mathrm{NH}_{3}\right]$ 199.1361; Found 199.1356.

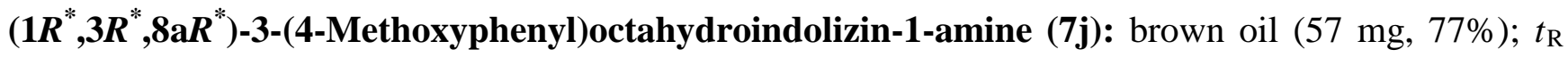
12.59; $R_{f} 0.17$ (acetone); IR (neat) v 2933, 2851, 1583, 1242, 1035, 828, 626; ${ }^{1} \mathrm{H}$ NMR (300 MHz, $\left.\mathrm{CDCl}_{3}\right) \delta 0.95-2.01(\mathrm{~m}, 9 \mathrm{H}), 2.57$ (dt, $\left.J=13.9,8.4 \mathrm{~Hz}, 1 \mathrm{H}\right), 2.73(\mathrm{~s}, 2 \mathrm{H}), 2.8(\mathrm{~d}, J=10.8 \mathrm{~Hz}, 1 \mathrm{H})$, 2.99 (t, $J=8.4 \mathrm{~Hz}, 1 \mathrm{H}), 3.27$ (ddd, $J=7.9,5.2,2.5 \mathrm{~Hz}, 1 \mathrm{H}), 3.78$ (s, 3H), 6.85, 7.24 (AA’XX', $J=8.7$ $\mathrm{Hz}, 4 \mathrm{H}) ;{ }^{13} \mathrm{C} \mathrm{NMR}\left(75 \mathrm{MHz}, \mathrm{CDCl}_{3}\right) \delta$ 23.9, 25.2, 25.9, 43.7, 51.6, 52.1, 55.1, 68.6, 69.0, 113.6, 
128.5, 134.9, 158.5; MS (70 eV) m/z (\%) 247 (M+1, 3), 246 (M+, 17), 203 (48), 202 (100), 162 (11), 134 (16), 132 (11), 84 (43); HRMS (EI) m/z: Calcd for $\mathrm{C}_{15} \mathrm{H}_{22} \mathrm{~N}_{2} \mathrm{O}$ 246.1732; Found 246.1723.

$\left(1 R^{*}, 3 R^{*}, 8 \mathrm{a} R^{*}\right)-3$-[4-(Trifluoromethyl)phenyl]octahydroindolizin-1-amine (7l): yellow oil (63 mg, 74\%); $t_{\mathrm{R}}$ 10.99; $R_{f} 0.45$ (EtOAc/MeOH, 8:2); IR (neat) $v$ 3024, 2939, 2851, 1553, 1457, 1322, 1162, 1117, 1066, 838; ${ }^{1} \mathrm{H}$ NMR (300 MHz, $\left.\mathrm{CDCl}_{3}\right) \delta$ 1.29-1.60 (m, 4H), 1.73-1.89 (m, 3H), 2.12 (ddd, $J=$ 10.9, 4.9, $2.4 \mathrm{~Hz}, 1 \mathrm{H}), 2.60-2.83$ (m, 5H), 3.19 (t, $J=8.5 \mathrm{~Hz}, 1 \mathrm{H}), 3.37-3.42$ (m, 1H), 7.46, 7.57 (AA’XX' system, $J=8.2 \mathrm{~Hz}, 4 \mathrm{H}) ;{ }^{13} \mathrm{C}$ NMR $\left(75 \mathrm{MHz}, \mathrm{CDCl}_{3}\right) \delta 23.9,25.2,26.0,44.2,51.7,52.5$, 68.7, 68.9, $124.2(\mathrm{q}, J=272.0 \mathrm{~Hz}), 125.3$ (q, $J=3.6 \mathrm{~Hz}), 127.6,129.0(\mathrm{q}, J=32.0 \mathrm{~Hz}), 147.8$; MS (70 eV) m/z (\%) $285\left(\mathrm{M}^{+}+1,1\right), 284\left(\mathrm{M}^{+}, 5\right), 265$ (7), 242 (8), 241 (62), 240 (100), 200 (6), 172 (9), 84 (12); HRMS (EI) $m / z$ : Calcd for $\mathrm{C}_{15} \mathrm{H}_{19} \mathrm{~F}_{3} \mathrm{~N}_{2}$ 284.1500, $\mathrm{C}_{15} \mathrm{H}_{16} \mathrm{~F}_{3} \mathrm{~N}$ [ $\mathrm{M}^{+}-\mathrm{NH}_{3}$ ] 267.1235; Found 267.1221.

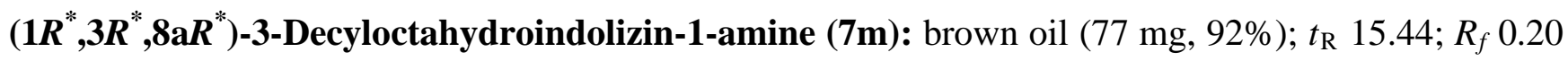
(EtOAc/MeOH, 7:3); IR (neat) $v$ 2921, 2851, 1560, 1467, 1458, 1387, 1147, 1121, 811, 721, 687; ${ }^{1} \mathrm{H}$ NMR (300 MHz, $\left.\mathrm{CDCl}_{3}\right) \delta 0.88(\mathrm{t}, J=6.7 \mathrm{~Hz}, 3 \mathrm{H}), 1.06(\mathrm{ddd}, J=13.6,8.1,2.7 \mathrm{~Hz}, 1 \mathrm{H}), 1.20-1.85$ (m, 27H), 2.04-2.19 (m, 2H), 2.35 (dt, $J=13.6,8.3 \mathrm{~Hz}, 1 \mathrm{H}), 3.12-3.20$ (m, 2H); ${ }^{13} \mathrm{C}$ NMR $(75 \mathrm{MHz}$, $\left.\mathrm{CDCl}_{3}\right) \delta 14.1,22.6,24.2,25.2,25.9,26.4,29.3,29.6,29.9,31.9,33.5,40.2,52.1,51.8,65.0,69.5 ; \mathrm{MS}$ (70 eV) m/z (\%) $280\left(\mathrm{M}^{+}+1,1\right), 279\left(\mathrm{M}^{+}, 1\right), 237$ (16), 236 (11), 140 (10), 139 (100), 124 (17), 122 (15), 110 (25), 96 (11); Anal. Calcd for $\mathrm{C}_{18} \mathrm{H}_{36} \mathrm{~N}_{2}$ : C, 77.08; H, 12.94; N, 9.99. Found: C, 76.72; H, $12.65 ; \mathrm{N}, 9.50$. 


\section{ASSOCIATED CONTENT}

\section{Supporting information}

${ }^{1} \mathrm{H},{ }^{13} \mathrm{C}$ and $2 \mathrm{D}$ NMR spectra, and selected X-ray data. This material is free of charge via the Internet at http://pubs.acs.org.

\section{AUTHOR INFORMATION}

\section{Corresponding author}

*E-mail: falonso@ua.es

\section{ACKNOWLEDGEMENTS}

This work was generously supported by the Spanish Ministerio de Economía y Competitividad (MINECO; CTQ2011-24151). M. J. A. and M. J. G.-S. acknowledge the Instituto de Síntesis Orgánica (ISO) of the Universidad de Alicante for both grants.

\section{REFERENCES}

(1) (a) Synthesis of Heterocycles via Metal-Catalyzed Reactions that Generate One or More Carbon-Heteroatom Bonds; Top. Heterocycl. Chem.; Wolfe, J. P., Ed.; Springer-Verlag: Berlin, 2013, Vol. 32. (b) Synopsis: Vo, C.-V. T.; Bode, J. W. J. Org. Chem. 2014, 79, 2809.

(2) For reviews, see: (a) Michael, J. P. Nat. Prod. Rep. 2005, 22, 603. (b) Michael, J. P. Nat. Prod. Rep. 2007, 24, 191. (c) Michael, J. P. Beilstein J. Org. Chem. 2007, 3, No. 27, doi:10.1186/1860-5397-3-27. (d) Michael, J. P. Nat. Prod. Rep. 2008, 25, 139.

(3) Edwardsj, M. W.; Daly, J. W. J. Nat. Prod. 1988, 51, 1188. 
(4) (a) Ritter, F. J.; Rotgans, I. E. M.; Tulman, E.; Verwiel, P. E. J; Stein, F. Experientia 1973, 29, 530. (b) Garrafo, H. M.; Spande, T. F.; Daly, J. W.; Baldessari, A.; Gross, E. G. J. Nat. Prod. 1993, 56, 357.

(5) (a) Ohmiya, S.; Kubo, H.; Otomasu, H.; Saito, K.; Murakoshi, I. Heterocycles 1990, 30, 537. (b) Greinwald, R.; Bachmann, P.; Lewis, G.; Witte, L.; Czygan, F.-C. Biochem. Syst. Ecol. 1995, 23, 547. (c) Asres, K.; Sporer, F.; Wink, M. Biochem. Syst. Ecol. 2004, 32, 915.

(6) (a) Collegate, S. M.; Dorling, P. R.; Huxtable, C. R. Aust. J. Chem. 1979, 32, 2257. (b) Molyneux, R. J.; James, L. F. Science 1982, 216, 190. (c) Olden, K.; Breton, P.; Grzegorzewski, K.; Yasuda, Y.; Gause, B. L.; Oredipe, O. A.; Newton, S. A.; White, S. L. Pharmacol. Ther. 1991, 50, 285.

(7) Bronner, S. M.; Im, G.-Y. J.; Garg, N. K. In Heterocycles in Natural Product Synthesis; Majumdar, K. C.; Chattopadhyay, S. K., Eds.; Wiley-VCH: Weinheim, 2011; pp. 221-265.

(8) Pansare, S. V.; Thorat, R. G. In Targets in Heterocyclic Systems. Chemistry and Properties; Attanasi, O. A.; Spinelli, D., Eds.; Società Chimica Italiana: Roma, 2013; Vol. 17, pp. 57-86.

(9) For a review, see: Jefford, C. W. Curr. Org. Chem. 2000, 4, 205.

(10) For a review, see: Lazzaroni, R.; Settambolo, R. Chirality 2011, 23, 730.

(11) For a review, see: Back, T. G. Can. J. Chem. 2009, 87, 1657.

(12) For a review, see: Brandi, A.; Cardona, F.; Cicchi, S.; Cordero, F. M.; Goti, A. Chem. Eur. J. 2009,15, 7808 .

(13) For a review, see: Remuson, R. Beilstein J. Org. Chem. 2007, 3, No. 32, doi:10.1186/18605397-3-32.

(14) For a review, see: Toyooka, N.; Tsuneki, H.; Kobayashi, S.; Zhou, D.; Kawasaki, M.; Kimura, I.; Sasaoka, T.; Nemoto, H. Curr. Chem. Biol. 2007, 1, 97. 
(15) For a review, see: Lapointe, G.; Kapat, A.; Weidner, K.; Renaud, P. Pure Appl. Chem. 2012, 84, 1633.

(16) For a review, see: Escolano, C.; Amat, M.; Bosch, J. Chem. Eur. J. 2006, 12, 8198.

(17) (a) Kel'in, A. V.; Sromek, A. W.; Gevorgyan, V. J. Am. Chem. Soc. 2001, 123, 2074. (b) Chai, W.; Kwok, A.; Wong, V.; Carruthers, N. I.; Wu, J. Synlett 2003, 13, 2086. (c) Zhang, L.; Li, X.; Liu, Y.; Zhang, D. Chem. Commun. 2015, 51, 6633.

(18) (a) Castaño, A. M.; Cuerva, J. M.; Echavarren, A. M. Tetrahedron Lett. 1994, 35, 7435. (b) Gracia, S.; Jerpan, R.; Pellet-Rostaing, S.; Popowycz, F.; Lemaire, M. Tetrahedron Lett. 2010, 51, 6290. (c) Jiang, C.; Frontier, A. J. Org. Lett. 2007, 9, 4939. (d) Ortega, N.; Tang, D.-T. D.; Urban, S.; Zhao, D.; Glorius, F. Angew. Chem. Int. Ed. 2013, 52, 9500.

(19) Teodoro, B. V. M.; Correia, J. T. M.; Coelho, F. J. Org. Chem. 2015, 80, 2529.

(20) See, ref. 17a (79:12:9 dr), ref. 17b (3.67:1.00 dr), ref. 18a (2:2:1 dr), ref. 18b (85-88\% de), ref. 18d (91:5:2:1 dr).

(21) For recent reviews and monographs on multicomponent reactions for the synthesis of heterocycles, see: (a) Arndtsen, B. A. Chem. Eur. J. 2009, 15, 302. (b) Top. Heterocycl. Chem. Vols. 23 and 25; Orru, R. V. A., Ruitjer, E., Eds.; Springer: Heidelberg, 2010. (c) Jian, B.; Rajale, T.; Wever, W.; Tu, S.-J.; Li, G. Chem. Asian J. 2010, 5, 2318. (d) Ruitjer, E.; Scheffelaar, R.; Orru, R. V. A. Angew. Chem. Int. Ed. 2011, 50, 6234. (e) Isambert, N.; Sanchez Duque, M. M.; Plaquevent, J.-C.; Génisson, Y.; Rodriguez, J.; Constantieux, T. Chem. Soc. Rev. 2011, 40, 1347. (f) Liu, Y. Arkivoc 2014, (i), 1.

(22) For reviews, see: (a) Alonso, F.; Yus, M. Pure Appl. Chem. 2008, 80, 1005. (b) Alonso, F.; Riente, P.; Yus, M. Acc. Chem. Res. 2011, 44, 379. (c) Alonso, F. In Metal Nanoparticles for Catalysis: Advances and Applications, RSC Catalysis Series No. 17; Tao, F., Ed.; The Royal Society of Chemistry: Cambridge (UK), 2014; Chapter 5, pp. 83-98.

(23) Alonso, F.; Moglie, Y.; Radivoy, G. Acc. Chem. Res. 2015, 48, 2516. 
(24) (a) Albaladejo, M. J.; Alonso, F.; Yus, M. Chem. Eur. J. 2013, 19, 5242. (b) Albaladejo, M. J.; Alonso, F.; González-Soria, M. J. ACS Catal. 2015, 5, 3446.

(25) Benaglia, M. Recoverable and Recyclable Catalysts; Wiley: Chichester (UK), 2009.

(26) For instance: compounds $5 \mathbf{j}$ and $5 \mathbf{l}$ were obtained in $61 \%$ and $49 \%$ yield, respectively, with $\operatorname{Pt}(5$ wt $\%$ )/C versus $86 \%$ and $55 \%$ with $\mathrm{PtO}_{2}$.

(27) Reviews: (a) Kotsuki, H.; Sasakura, N. In Comprehensive Enantioselective Organocatalysis; Dalko, P. I., Ed.; Wiley-VCH: Weinheim, 2013; Vol. 1, pp. 3-31. (b) Ishikawa, H.; Shiomi, Org. Biomol. Chem. 2016, 14, 409.

(28) Review: Yan, W.; Shi, X.; Zhong, C. Asian J. Org. Chem. 2013, 2, 904.

(29) Reviews: (a) Yoo, W.-J.; Zhao, L.; Li, C.-J. Aldrichim. Acta 2011, 44, 43. (b) Tron, G. C. Eur. J. Org. Chem. 2013, 1849.

(30) For a review, see: Mahatthananchai, J.; Dumas, A. M.; Bode, J. W. Angew. Chem. Int. Ed. 2012, 51, 10954-10990.

(31) CCDC-998093 (5a) contains the supplementary crystallographic data for this paper. These data can be obtained free of charge from The Cambridge Crystallographic Data Centre via www.ccdc.cam.ac.uk/data_request/cif.

(32) (a) SAINT version 6.28A: Area Detector Integration Software, Siemens Industrial Automation Inc., Madison, WI, 1995. (b) Sheldrick, G. M.; SADABS: Area Detector Absorption Correction; Göttingen University, Göttingen, Germany, 1996. 


\section{Table of Contents}

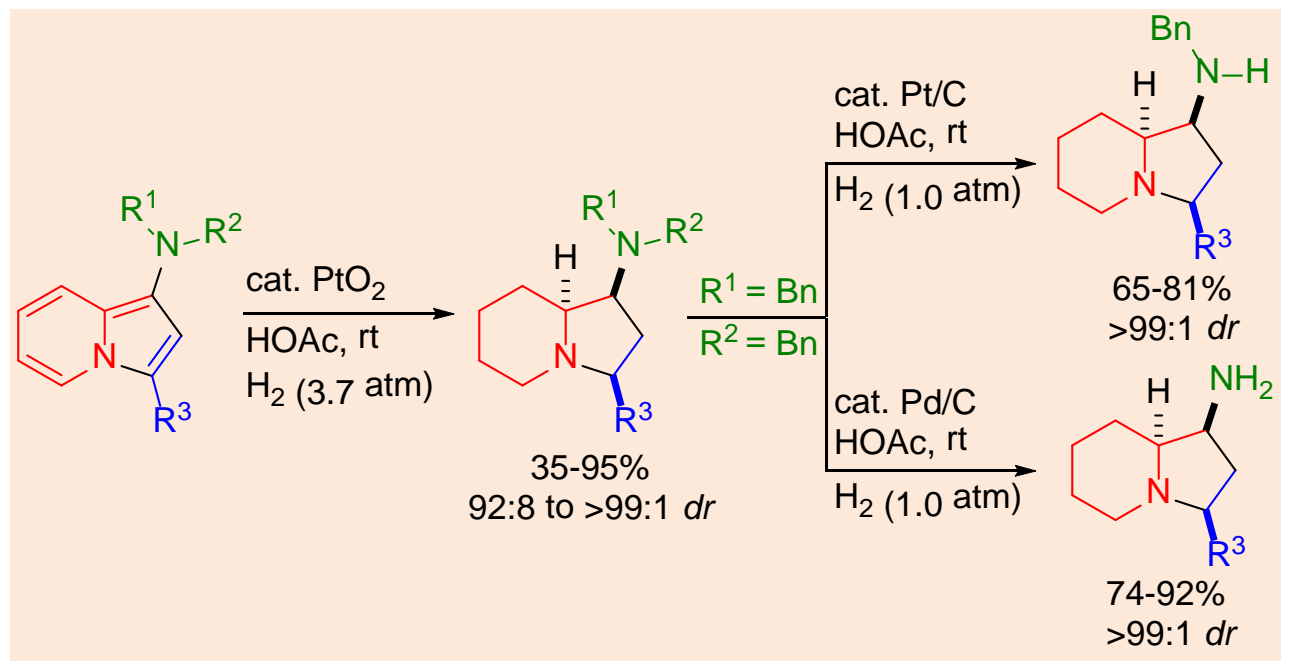

